\title{
Lipid Peroxidation and Antioxidants in Arterial Hypertension
}

\author{
Teresa Sousa, Joana Afonso, Félix Carvalho and António Albino-Teixeira
}

Additional information is available at the end of the chapter

http://dx.doi.org/10.5772/50346

\section{Introduction}

This chapter aims at giving a critical overview of the major oxidant and antioxidant changes in arterial hypertension, summarizing the experimental and clinical evidence about the involvement of oxidative stress in the pathophysiology of hypertension, either as a cause or a consequence of this disease. This review also provides a description of the biomarkers commonly used to evaluate lipid peroxidation and antioxidant defenses in experimental and human hypertension. Finally, we review the strategies (antioxidants, antihypertensive drugs) known to prevent or ameliorate oxidative damage, both in animal models of hypertension and hypertensive patients.

\section{Pathophysiological role of oxidative stress in arterial hypertension}

\subsection{ROS sources and oxidative pathways involved in the pathogenesis of hypertension}

In aerobic organisms, the beneficial effects of oxygen come with the price of reactive oxygen species (ROS) formation. These highly bioactive and short-lived molecules can interact with lipids, proteins and nucleic acids, causing severe molecular damage. However, living organisms have evolved specific mechanisms to adapt to the coexistence of ROS. In physiological conditions, there is a delicate balance between oxidants and antioxidants that not only protects our cells from the detrimental effects of reactive oxygen species (ROS), but also allows the existence of redox signaling processes that regulate cellular and organ functions. However, the disruption of redox homeostasis, leading to persistent high levels of ROS, is potentially pathological [1, 2]. Besides ROS, another group of molecules collectively designated as reactive nitrogen species (RNS) also exerts important functions in diverse physiological and pathological redox signaling processes. The excess of RNS is often termed nitrosative stress $[3,4]$. 
ROS can be classified into two main categories: free radicals [e.g. superoxide $\left(\mathrm{O}_{2-}^{-}\right)$, hydroxyl (HO), peroxyl (ROO)], which are highly reactive species due to the presence of one or more unpaired electrons, and non-radical oxidants [e.g. singlet oxygen $\left({ }^{1} \mathrm{O}_{2}\right)$ hydrogen peroxide $\left(\mathrm{H}_{2} \mathrm{O}_{2}\right)$, hypochlorous acid $\left.(\mathrm{HOCl})\right]$ that have generally more specific reactivity and higher stability $[3,5,6]$. RNS include nitric oxide $(\cdot \mathrm{NO})$ and nitrogen dioxide radicals $\left(\cdot \mathrm{NO}_{2}\right.$ and also non radicals such as nitrous acid $\left(\mathrm{HNO}_{2}\right)$, peroxynitrite $(\mathrm{ONOO}-)$, peroxynitrous acid $(\mathrm{ONOOH})$ and alkyl peroxynitrites (ROONO) [3]. Among biological ROS and RNS, $\mathrm{O}_{2-}$, $\mathrm{H}_{2} \mathrm{O}_{2}$, $\mathrm{NO}$ and $\mathrm{ONOO}^{-}$appear to be especially relevant in neuronal, renal and vascular control of blood pressure $[3,7,8]$ (Table 1). Major sources of ROS (and also RNS) within these systems include, but are not limited to, NADPH oxidases, xanthine oxidase, mitochondrial respiratory chain enzymes, $\mathrm{NO}$ synthases and myeloperoxidase $[3,8,9]$.

\begin{tabular}{|c|c|c|}
\hline & Free radicals & Non radical oxidants \\
\hline \multirow{3}{*}{ ROS } & $\mathrm{O}_{2}^{--}$ & $\mathrm{H}_{2} \mathrm{O}_{2}$ \\
& $\mathrm{HO}$ & $\mathrm{HClO}$ \\
& $\mathrm{ROO}$ & ONOO- \\
\hline \multirow{2}{*}{ RNS } & $\mathrm{NO}$ & . \\
\hline
\end{tabular}

Table 1. Reactive oxidant species involved in cardiovascular and renal physiology or pathophysiology

NADPH oxidases (Nox) are enzyme complexes that catalyze the reduction of molecular oxygen using NADPH as an electron donor. Generally, the product of the electron transfer reaction is $\mathrm{O}_{2}-$ but $\mathrm{H}_{2} \mathrm{O}_{2}$ is also rapidly formed from dismutation of Nox-derived $\mathrm{O}_{2}$ - due to the presence of superoxide dismutase (SOD) in the cells or by spontaneous reaction. Nox-derived ROS have been shown to play a role in host defense and also in diverse signaling processes [10]. The Nox family comprises seven members (Nox1-5 and Duox1-2) with distinct tissue distribution and functions $[10,11]$. So far, only Nox1, Nox2 and Nox4 have been shown to play relevant roles in hypertension pathophysiology $[5,8,10]$. These isoforms are localized in major sites of blood pressure control. For example, Nox1, Nox2 and Nox4 are expressed in the central nervous system where they appear to regulate sympathetic nerve activity [8]. Nox2 and Nox4 participate in the regulation of renal functions and contribute to end-organ damage associated with hypertension $[8,12]$. In the vasculature, Nox1 controls smooth muscle cell growth and migration, Nox2 contributes to endothelial dysfunction and Nox4 controls vascular smooth muscle cell differentiation and improves endothelial-dependent vasodilatation $[8,13,14]$.

Xanthine oxidoreductase has two inter-convertible forms, xanthine dehydrogenase (XDH) and xanthine oxidase $(\mathrm{XO})$, that participate in purines metabolism catalyzing the conversion of hypoxanthine to xanthine and xanthine to uric acid [15, 16]. XDH preferentially uses $\mathrm{NAD}^{+}$as an electron acceptor while the oxidase reduces molecular oxygen in a reaction that generates $\mathrm{O}_{2}-$ and $\mathrm{H}_{2} \mathrm{O}_{2}[15,16]$. The $\mathrm{XO}$ form predominates in oxidative stress conditions and may contribute to endothelium dysfunction due to its localization in the luminal surface of vascular endothelium [16, 17]. Besides the production of ROS by $\mathrm{XO}$, both $\mathrm{XDH}$ and $\mathrm{XO}$ generate uric acid which possesses antioxidant properties, such as scavenging of $\mathrm{ONOO}^{-}$and $\mathrm{HO}$, prevention of oxidative inactivation of endothelium enzymes and stabilization of Vitamin $\mathrm{C}$ 
[18-22]. On the other hand, uric acid may also have prooxidant and proinflammatory effects $[23,24]$. Indeed, high systemic levels of uric acid are associated with increased cardiovascular disease and poor outcome but it is not clear whether these effects reflect deleterious actions of uric acid or the oxidative damage caused by XO-derived ROS [23, 25].

Mitochondrial respiratory chain enzymes are primary intracellular sources of ROS. More than $90 \%$ of the total oxygen consumed by aerobic organisms is utilized by mitochondrial oxidases which produce ATP in a process coupled to the reduction of cellular oxygen to water [26]. About $1-4 \%$ of the oxygen used in these reactions is converted to $\mathrm{O}_{2}{ }^{-}$and $\mathrm{H}_{2} \mathrm{O}_{2}$ which can be largely detrimental to mitochondrial functions if not adequately detoxified [2628]. ROS levels in the mitochondria are regulated by the respiratory rate and manganese SOD [29]. Hypertensive animals have increased mitochondrial ROS production in the vessels, kidney and CNS [30-32].

NO synthases (NOS) constitute a family of enzyme isoforms (neuronal NOS, nNOS; inducible NOS, iNOS; endothelial NOS, eNOS) that produce $\mathrm{NO}$ in a reaction that converts L-arginine to L-citrulline [28]. However, in conditions of limited bioavailability of the cofactor tetrahydrobiopterin, or the substrate L-arginine, these enzymes become unstable and reduce molecular oxygen to $\mathrm{O}_{2}$ - instead of $\mathrm{NO}$ production (uncoupled NOS) [28, 29]. NOS uncoupling is more often described for eNOS and is triggered by oxidative/nitrosative stress $[28,33]$. Numerous experimental studies have shown that arterial hypertension is associated with eNOS dysregulation and endothelial dysfunction [34, 35].

Myeloperoxidase (MPO) is a heme protein secreted by activated neutrophiles and monocytes in inflammatory conditions and produces several oxidizing molecules that can affect lipids and proteins [28, 36]. MPO uses $\mathrm{H}_{2} \mathrm{O}_{2}$ to produce ROS such as $\mathrm{HOCl}$, chloramines, tyrosyl radicals and nitrogen dioxides [36, 37]. Although MPO-derived ROS have a primary role in microbial killing, they also cause tissue damage in the heart, vessels, kidney and brain and appear to contribute to endothelial dysfunction [37, 40]. Figure 1 illustrates the major sources of ROS and/or RNS generation.

Of all the putative oxidative pathways involved in the pathogenesis of hypertension, the impairment of endothelial-dependent vasorelaxation by $\mathrm{O}_{2}-$ is by far the most studied [4144]. In conditions of increased $\mathrm{O}_{2}$ - bioavailability, this ROS rapidly inactivates endothelialderived $\mathrm{NO}$ leading to endothelial dysfunction [41]. In addition, $\mathrm{O}_{2}-$ may also modulate vascular tone by increasing intracellular $\mathrm{Ca}^{2+}$ concentration in vascular smooth muscle cells and endothelial cells [45]. The imbalance between $\mathrm{O}_{2 \cdot-}$ and $\mathrm{NO}$ also affects the renal function, leading to enhanced sodium reabsorption and increased ONOO- formation, which contributes to tissue damage $[12,46]$. In the $\mathrm{CNS}$, elevated $\mathrm{O}_{2}-$ generation also appears to contribute to hypertension by reducing the cardiovascular depressor actions of $\mathrm{NO}$ in the rostral ventrolateral medulla [47]. In recent years $\mathrm{H}_{2} \mathrm{O}_{2}$ has also emerged as a pivotal molecule in the pathophysiology of arterial hypertension [48-50]. Of note, $\mathrm{H}_{2} \mathrm{O}_{2}$ seems to be even more harmful than $\mathrm{O}_{2}-$ due to its higher life span and diffusibility within and between cells [7, 51]. Furthermore, the conversion of $\mathrm{O}_{2}$ to $\mathrm{H}_{2} \mathrm{O}_{2}$ appears to be favored in cardiovascular diseases since the expression and activity of SOD is enhanced by 
inflammatory cytokines in hypertension or in response to the pressor peptide, angiotensin II [7]. Several prohypertensive effects have been described for $\mathrm{H}_{2} \mathrm{O}_{2}$, such as increased vasoconstriction, vascular hypertrophy and hyperplasia, decreased diuresis and natriuresis and also increased spinal sympathetic outflow [7, 50, 52-58]. Increasing evidence has also shown that $\mathrm{H}_{2} \mathrm{O}_{2}$ amplifies oxidative stress by stimulating ROS generation by NADPH oxidases, $\mathrm{XO}$ and eNOS $[7,51]$. In addition, $\mathrm{H}_{2} \mathrm{O}_{2}$ also appears to enhance the activation of the intrarenal renin-angiotensin system, a major regulator of blood pressure and renal function [49]. Altogether, these effects propagate $\mathrm{H}_{2} \mathrm{O}_{2}$ generation and prolong the redox pathologic signaling involved in blood pressure dysregulation. The oxidative mechanisms contributing to hypertension are summarized in Table 2.

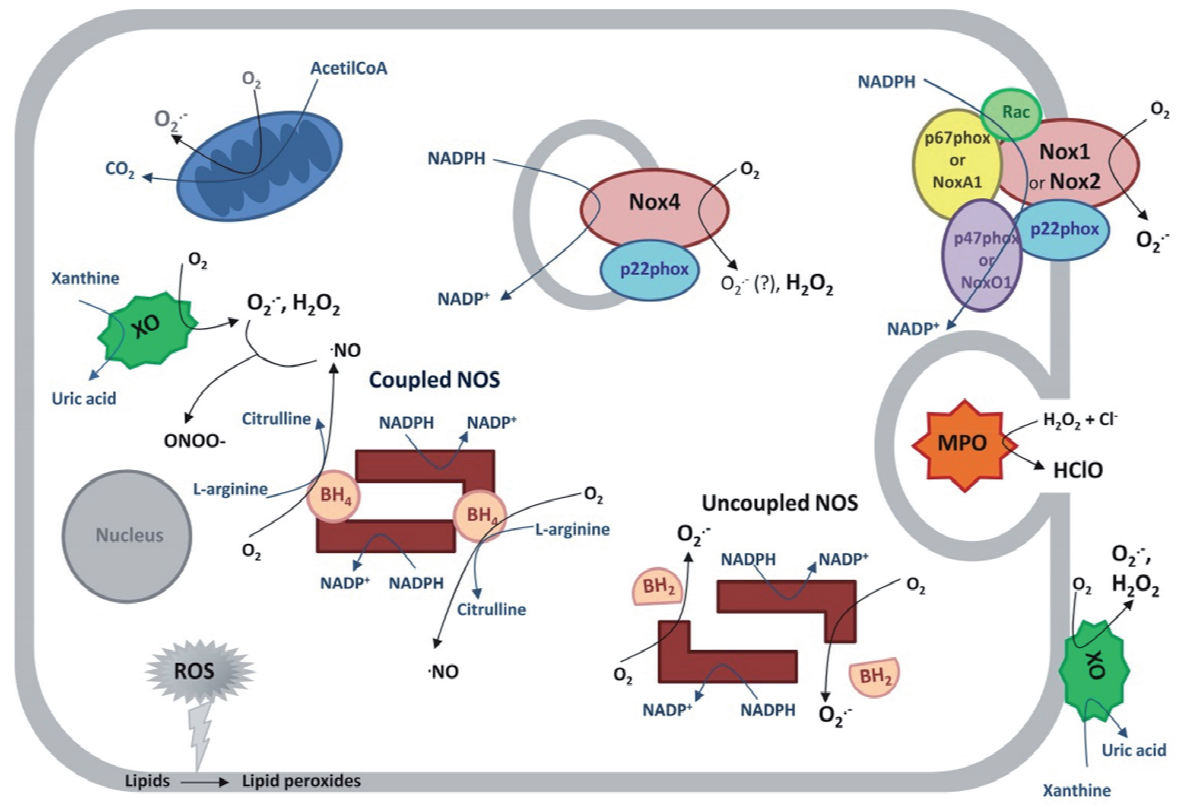

Figure 1. Sources of ROS and/or RNS generation - In normal cells, 1-2\% of electrons carried by the mitochondrial electron transport chain leak from this pathway and pass directly to oxygen generating superoxide radical $\left(\mathrm{O}_{2 \cdot-}\right)$ which can be a source of other ROS. $\mathrm{O}_{2} \cdot-$ can also be formed by xanthine oxidase $(\mathrm{XO})$ which catalyzes the oxidation of hypoxanthine and xanthine. All NOX enzymes utilize $\mathrm{NADPH}$ as an electron donor and catalyze transfer of electrons to molecular oxygen to generate $\mathrm{O}_{2}$ and/or $\mathrm{H}_{2} \mathrm{O}_{2}$. Nitric Oxide synthases (NOS) generate $\mathrm{NO}$ and L-citrulline from arginine and $\mathrm{O}_{2}$. Under pathologic conditions of oxidative stress, or when tetrahydrobiopterin $\left(\mathrm{BH}_{4}\right)$ or L-arginine are deficient, NOS enzymes become structurally unstable (uncoupled NOS) resulting in production of $\mathrm{O}_{2}$-- rather than -NO. Activated monocytes also secrete a heme enzyme, myeloperoxidase(MPO), that uses $\mathrm{H}_{2} \mathrm{O}_{2}$ as a substrate to generate products that can oxidize lipids and proteins. One of these oxidants is hypochlorous acid (HOCI) which plays a critical role in host defenses against invading bacteria, viruses, and tumor cells but may also injure normal tissue. Within cell membranes, ROS can trigger lipid peroxidation, a self-propagating chain-reaction that can result in significant tissue damage. 


\begin{tabular}{|c|c|c|}
\hline Affected organ & Oxidative stress consequences & $\begin{array}{c}\text { Major ROS and RNS } \\
\text { involved }\end{array}$ \\
\hline Vasculature & $\begin{array}{l}\text { Impaired endothelium-dependent } \\
\text { vasodilation } \\
\text { Increased vasoconstriction } \\
\text { Increased hypertrophy and hyperplasia }\end{array}$ & $\begin{array}{l}\mathrm{O}_{2 \cdot} \cdot, \cdot \mathrm{NO}, \mathrm{ONOO}^{-} \\
\mathrm{O}_{2 \cdot} \cdot \mathrm{H}_{2} \mathrm{O}_{2} \\
\mathrm{O}_{2} \cdot, \mathrm{H}_{2} \mathrm{O}_{2}\end{array}$ \\
\hline Kidney & $\begin{array}{l}\text { Decreased blood flow } \\
\text { Increased salt reabsorption } \\
\text { Tissue damage }\end{array}$ & $\begin{array}{l}\mathrm{O}_{2 \cdot-}, \mathrm{H}_{2} \mathrm{O}_{2} \\
\mathrm{O}_{2} \cdot, \mathrm{H}_{2} \mathrm{O}_{2} \\
\mathrm{HO}, \mathrm{HClO}, \mathrm{ONOO}-\end{array}$ \\
\hline Brain/Spinal cord & Increased sympathetic efferent activity & $\mathrm{O}_{2} \cdot, \mathrm{H}_{2} \mathrm{O}_{2}$ \\
\hline
\end{tabular}

Table 2. Putative oxidative pathways leading to arterial hypertension

\subsection{Evidence for redox changes in experimental and human hypertension}

In the last two decades several studies have consistently observed increased oxidative stress in experimental and human arterial hypertension. Studies in diverse experimental models of hypertension have demonstrated raised prooxidant activity and ROS levels, altered antioxidant defenses and increased ROS-mediated damage, both at peripheral and central sites of cardiovascular regulation $[8,33,59]$. In human hypertensive patients there is also evidence of redox dysfunction. $\mathrm{O}_{2}-$ release from peripheral polymorphonuclear leucocytes is higher in hypertensive patients than in normotensive subjects [60]. Plasma $\mathrm{H}_{2} \mathrm{O}_{2}$ production is also raised in hypertensive patients. Furthermore, among still normotensive subjects, those with a family history of hypertension have a higher $\mathrm{H}_{2} \mathrm{O}_{2}$ production [61, 62]. An elevation of several oxidative stress byproducts, such as malondialdehyde, 8-isoprostanes, 8-oxo-2'-deoxyguanosine, oxidized low density lipoproteins, carbonyl groups and nitrotyrosine has also been observed in plasma or serum, urine or blood cells of hypertensive patients [63-66]. Furthermore, both enzymatic and non-enzymatic antioxidant defenses appear to be significantly reduced in human hypertension [65, 67]. Alterations of redox biomarkers in human hypertension are summarized in Table 3.

\begin{tabular}{|l|l|l|c|l|}
\hline & Biomarker & Evaluated in: & $\begin{array}{c}\text { Alteration in } \\
\text { hypertensive } \\
\text { patients }\end{array}$ & References \\
\hline \multirow{2}{*}{ ROS/RNS } & $\mathrm{O}_{2}-$ & $\uparrow$ & {$[60]$} \\
\cline { 2 - 5 } & $\mathrm{H}_{2} \mathrm{O}_{2}$ & Peripheral PMN & $\uparrow$ & {$[61,62]$} \\
& & Plasma & $\uparrow$ & {$[68]$} \\
\hline & $\mathrm{NOx}$ & Lymphocytes & $\downarrow$ & {$[69]$} \\
& & Plasma & Urine & {$[70]$} \\
\hline
\end{tabular}




\begin{tabular}{|c|c|c|c|c|}
\hline & Biomarker & Evaluated in: & $\begin{array}{c}\text { Alteration in } \\
\text { hypertensive } \\
\text { patients }\end{array}$ & References \\
\hline $\begin{array}{l}\text { Prooxidant } \\
\text { enzymes }\end{array}$ & \begin{tabular}{|l|} 
NADPH oxidase \\
activity \\
p22phox (Nox subunit) \\
mRNA and protein \\
expression
\end{tabular} & $\begin{array}{l}\text { Mononuclear cells } \\
\text { Mononuclear cells }\end{array}$ & $\begin{array}{l}\text { 个 } \\
\uparrow\end{array}$ & {$\left[\begin{array}{l}{[71]} \\
{[71]}\end{array}\right.$} \\
\hline \multirow[t]{6}{*}{$\begin{array}{l}\text { Oxidative or } \\
\text { nitrosative stress } \\
\text { byproducts }\end{array}$} & $\begin{array}{l}\text { Malondialdehyde } \\
\text { (MDA)/Thiobarbituric } \\
\text { acid reactive } \\
\text { substances (TBARS) }\end{array}$ & $\begin{array}{l}\text { Plasma } \\
\text { Erythrocytes } \\
\text { Mononuclear cells } \\
\text { and whole blood }\end{array}$ & $\begin{array}{l}\uparrow \\
\uparrow \\
\uparrow\end{array}$ & $\begin{array}{l}{[67,72]} \\
{[64,73,74]} \\
{[65]}\end{array}$ \\
\hline & $\begin{array}{l}\text { F2-Isoprostane (or 8- } \\
\text { isoprostane or 8-epi- } \\
\text { PGF2 } \alpha \text { ) }\end{array}$ & $\begin{array}{l}\text { Plasma } \\
\text { Urine }\end{array}$ & $\uparrow$ & $\begin{array}{l}{[63,66,74]} \\
{[63,74,75]}\end{array}$ \\
\hline & $\begin{array}{l}\text { 8-Oxo-2'- } \\
\text { deoxyguanosine }\end{array}$ & & $\begin{array}{l}\uparrow \\
\uparrow\end{array}$ & {$\left[\begin{array}{l}{[65]} \\
{[76,77]}\end{array}\right.$} \\
\hline & \begin{tabular}{|l|} 
Carbonyl groups \\
\end{tabular} & Serum & $\uparrow$ & [64] \\
\hline & $\begin{array}{l}\text { Oxidized low density } \\
\text { lipoproteins }\end{array}$ & Plasma & $\uparrow$ & {$[63,78]$} \\
\hline & 3-Nitrotyrosine & Plasma & $\uparrow$ & {$[66,79]$} \\
\hline Redox status & $\begin{array}{l}\text { GSSG/GSH } \\
\text { GSH/GSSG }\end{array}$ & $\begin{array}{l}\text { Mononuclear cells } \\
\text { and whole blood } \\
\text { Erythrocytes }\end{array}$ & $\downarrow$ & {$[65]$} \\
\hline \multirow[t]{5}{*}{ Antioxidants } & GSH & $\begin{array}{l}\text { Mononuclear cells } \\
\text { and whole blood } \\
\text { Erytrocytes }\end{array}$ & $\downarrow$ & {$\left[\begin{array}{l}{[65]} \\
{[64]}\end{array}\right.$} \\
\hline & Uric acid & $\begin{array}{l}\text { Plasma } \\
\text { Serum }\end{array}$ & $\begin{array}{l}\uparrow \\
\uparrow \\
\end{array}$ & $\begin{array}{l}{[79]} \\
{[80]}\end{array}$ \\
\hline & $\begin{array}{l}\text { Vitamin C } \\
\text { (ascorbic acid) }\end{array}$ & $\begin{array}{l}\text { Plasma } \\
\text { Serum }\end{array}$ & $\begin{array}{l}\downarrow \\
\downarrow\end{array}$ & \begin{tabular}{|l}
$67]$ \\
{$[81]$} \\
\end{tabular} \\
\hline & $\begin{array}{l}\begin{array}{l}\text { Vitamin E } \\
(\alpha-\text { Tocopherol, }\end{array} \\
\end{array}$ & Erytrhocytes & $\downarrow$ & {$[67]$} \\
\hline & \begin{tabular}{|l|} 
Total antioxidant status \\
(TAS) \\
Ferric reducing activity \\
of plasma (FRAP)
\end{tabular} & $\begin{array}{l}\text { Plasma } \\
\text { Plasma }\end{array}$ & $\downarrow$ & {$\left[\begin{array}{l}{[63,82]} \\
{[74,83]}\end{array}\right.$} \\
\hline
\end{tabular}




\begin{tabular}{|l|l|l|c|l|}
\hline & Biomarker & Evaluated in: & $\begin{array}{c}\text { Alteration in } \\
\text { hypertensive } \\
\text { patients }\end{array}$ & References \\
\hline \multirow{2}{*}{ SOD activity } & Erythrocytes & $\downarrow$ & {$[64,74]$} \\
& $\begin{array}{l}\text { Whole blood and } \\
\text { mononuclear cells }\end{array}$ & $\downarrow$ & {$[65]$} \\
\cline { 2 - 5 } & Catalase activity & $\begin{array}{l}\text { Erythrocytes } \\
\text { Whole blood and } \\
\text { mononuclear cells }\end{array}$ & $\downarrow$ & {$[64,74]$} \\
\cline { 2 - 5 } & $\begin{array}{l}\text { Glutathione peroxidase } \\
\text { activity }\end{array}$ & $\begin{array}{l}\text { Erythrocytes } \\
\text { Whole blood and } \\
\text { mononuclear cells }\end{array}$ & $\downarrow$ & {$[64,74]$} \\
\cline { 2 - 5 } & $\begin{array}{l}\text { Glutathione-S- } \\
\text { transferase activity }\end{array}$ & Erythrocytes & $\uparrow$ & {$[64]$} \\
\hline
\end{tabular}

NOx- nitrites and nitrates; PMN - Polymorphonuclear leucocytes; GSH - reduced glutathione; GSSG- oxidized glutathione;

Table 3. Altered oxidative/nitrosative stress biomarkers in human arterial hypertension

\subsection{Oxidative stress as a cause for arterial hypertension}

Whether oxidant imbalance is a cause or a consequence of high blood pressure remains a debatable question. The hypothesis that oxidative stress contributes to arterial hypertension is supported by several lines of evidence: (1) the induction of oxidative stress by the administration of lead or the glutathione synthesis inhibitor, buthionine sulfoximine, or the SOD inhibitor, sodium diethyldithiocarbamate, increases blood pressure in rats $[48,84] ;(2)$ the infusion of $\mathrm{H}_{2} \mathrm{O}_{2}$ into the renal medulla leads to hypertension [48]; the treatment of hypertensive animals with antioxidants or inhibitors of ROS production prevents or attenuates hypertension [50, 85-87]; (3) the manipulation of genes related to ROS generation or elimination can alter blood pressure [88, 89]; (4) the in vitro exposure of cells and tissues to exogenous oxidants reproduces events involved in the pathophysiology of hypertension [43]; (5) systemic and tissue redox dysfunction appears to precede the blood pressure elevation [90].

\subsection{Oxidative stress as a consequence of arterial hypertension}

Arterial hypertension is associated with oscillatory shear stress and vascular stretch caused by increased vascular pressure. These mechanical forces are known to induce oxidative stress and vascular damage [91]. Furthermore, there is evidence that lowering blood pressure per se causes reduction of oxidative stress and improvement in endothelial function [92]. Several antihypertensive drugs with distinct mechanisms of action have been shown to decrease oxidant biomarkers in experimental and human hypertension [93-95]. However, there is limited evidence supporting the use of antioxidants to lower blood pressure in human hypertensive patients [5, 92]. Nevertheless, the failure of these studies does not 
exclude a role for oxidative stress in human essential hypertension but instead suggests that the antioxidant supplementation approach was not the appropriate therapeutic strategy [96].

\section{Biomarkers of redox status in arterial hypertension}

The evaluation of redox status may provide valuable information about the pathogenesis and progression of arterial hypertension and related cardiovascular and renal diseases. However, the short lifetime of ROS turns their assessment in animal models and humans a significant challenge, leading to a growing interest in the development and validation of oxidative stress biomarkers. Traditional approaches to evaluate oxidant status have frequently relied on indirect measurements of ROS bioavailability (e.g. evaluation of prooxidant and antioxidant activity, oxidized products from ROS and the GSH/GSSG ratio) as indicators of normal biological processes, pathogenic processes, or pharmacologic responses to therapeutic intervention [9, 96-99].

A biomarker of oxidative stress is classically defined as a biological molecule whose chemical structure has been modified by ROS and that can be used to reliably assess oxidative stress status in animal models and humans [100]. The ideal biomarker of oxidative stress depends on its ability to contribute to an early indication of disease severity and/or its progression, as well as to evaluate therapy efficacy. The measurement of redox status biomarkers may also help to clarify the pathophysiologic mechanisms mediating oxidative injury and may allow the prediction of disease. Ideally, biomarkers of oxidative damage for human studies would be evaluated in specimens that can be collected relatively easily, such as blood or urine. However, to serve these purposes, an ideal biomarker of oxidative damage should fulfill several conditions, such as: a) being a stable product, not susceptible to artifactual induction, oxidation, or loss during sample handling, processing, analysis, and storage; b) having a well-established relationship with the generation of ROS and/or progression of disease; c) allowing direct assessment in a target tissue or being able to generate a valid substitute that quantitatively reflects the oxidative modification of the target tissue; d) being present at concentrations high enough to be a significant detectable product; e) showing high specificity for the reactive species in question and free of erroneous factors from dietary intake; f) being noninvasive; g) being measurable by a specific, sensitive, reproducible and inexpensive assay; h) being measurable across populations; i) being present in concentrations that do not vary widely in the same persons under the same conditions at different times [97].

\subsection{Systemic and tissue antioxidant defenses}

ROS are involved in many biological processes including cell growth, differentiation, apoptosis, immunity and defense against micro-organisms [1, 101, 102]. Low or moderate concentrations of ROS are beneficial for living organisms. However, high concentrations of ROS can cause direct damage of macromolecules such as DNA, proteins, carbohydrates, and lipids, or disrupt redox signaling and control pathways, leading to a myriad of human 
diseases [103]. ROS bioavailability is determined by the balance between their production by prooxidant enzymes and their clearance by various antioxidant compounds and enzymes [1]. As defined by Halliwell and Gutteridge, an antioxidant is any substance that, at low concentration, is able to significantly delay or inhibit the oxidation of an oxidizable substrate [104]. Biological antioxidant defenses have evolved to match the diversity of prooxidants and several enzymatic and non-enzymatic molecules exist in cells and body fluids to control ROS levels within the physiological range [105]. The coordinated action of antioxidants results in the interception and deactivation of the damaging species. For example, the radical chain events initiated by free radicals can be terminated by the interaction of radicals with different non-enzymatic antioxidants [e.g. GSH, ascorbic acid, uric acid, $\alpha$-tocopherol, etc] or prevented by specialized enzymatic defenses such as SOD, catalase and glutathione peroxidase (GPx) [105, 106]. The reduction of antioxidants bioavailability disrupts redox homeostasis leaving organisms more vulnerable to oxidative damage. Therefore, antioxidants may be useful biomarkers for risk stratification and disease prognostication.

\subsection{Enzymatic antioxidants defenses}

All eukaryotic cells possess powerful antioxidant enzymes which are responsible for neutralizing ROS.The first line of defense against ROS is achieved by SOD which is active in catalyzing the detoxification of $\mathrm{O}_{2}-$. This radical can be readily converted into $\mathrm{H}_{2} \mathrm{O}_{2}$ by SOD enzymes present in the cytosol and organelles (Cu,Zn-SOD or SOD-1), mitochondria (MnSOD or SOD-2) and extracellular fluids (EC-SOD or SOD-3) [36, 107, 108]. $\mathrm{H}_{2} \mathrm{O}_{2}$ generated in this reaction can be further decomposed to water and oxygen. This is achieved primarily by catalase in the peroxisomes and also by GPx enzymes in the cytosol and mitochondria [107, 108]. GPx are selenium-containing enzymes whose activity is dependent on GSH availability [108]. Besides neutralizing $\mathrm{H}_{2} \mathrm{O}_{2}$, GPx also degrades lipid hydroperoxides to lipid alcohols [36]. These reactions lead to the oxidation of GSH to GSSG. Catalase and GPx are differentially required for the clearance of high-levels or low-levels of $\mathrm{H}_{2} \mathrm{O}_{2}$, respectively [36]. Figure 2 illustrates major antioxidant enzymatic pathways.

In addition to these key antioxidant enzymatic defenses, there are other specialized enzymes with direct and/or indirect antioxidant functions. Glutathione reductase (GR) is responsible for the replenishment of GSH from GSSG disulphide. Glutathione-S-transferase catalyzes the conjugation of GSH with reactive electrophiles and is also involved in the detoxification of some carbonyl-, peroxide- and epoxide-containing metabolites produced within the cell in oxidative stress conditions [109]. Peroxiredoxins are selenium-independent enzymes that decompose $\mathrm{H}_{2} \mathrm{O}_{2}$, organic hydroperoxides and peroxynitrite [110]. Thioredoxin (Trx) and glutaredoxin (Grx) systems include several enzymes that regulate the thiol-disulphide state of proteins and influence their structure and function [110]. Trx isoforms reduce disulphide bonds in proteins, especially in peroxiredoxins and Trx reductase regenerates the oxidized Trx. Grx protects proteins SH-groups from irreversible oxidation by catalyzing Sglutathionylation and restores functionally active thiols through catalysis of deglutathionylation [110]. Grx enzymes are functionally coupled to GR which reduces the GSSG produced in the deglutathionylation reaction [110]. 


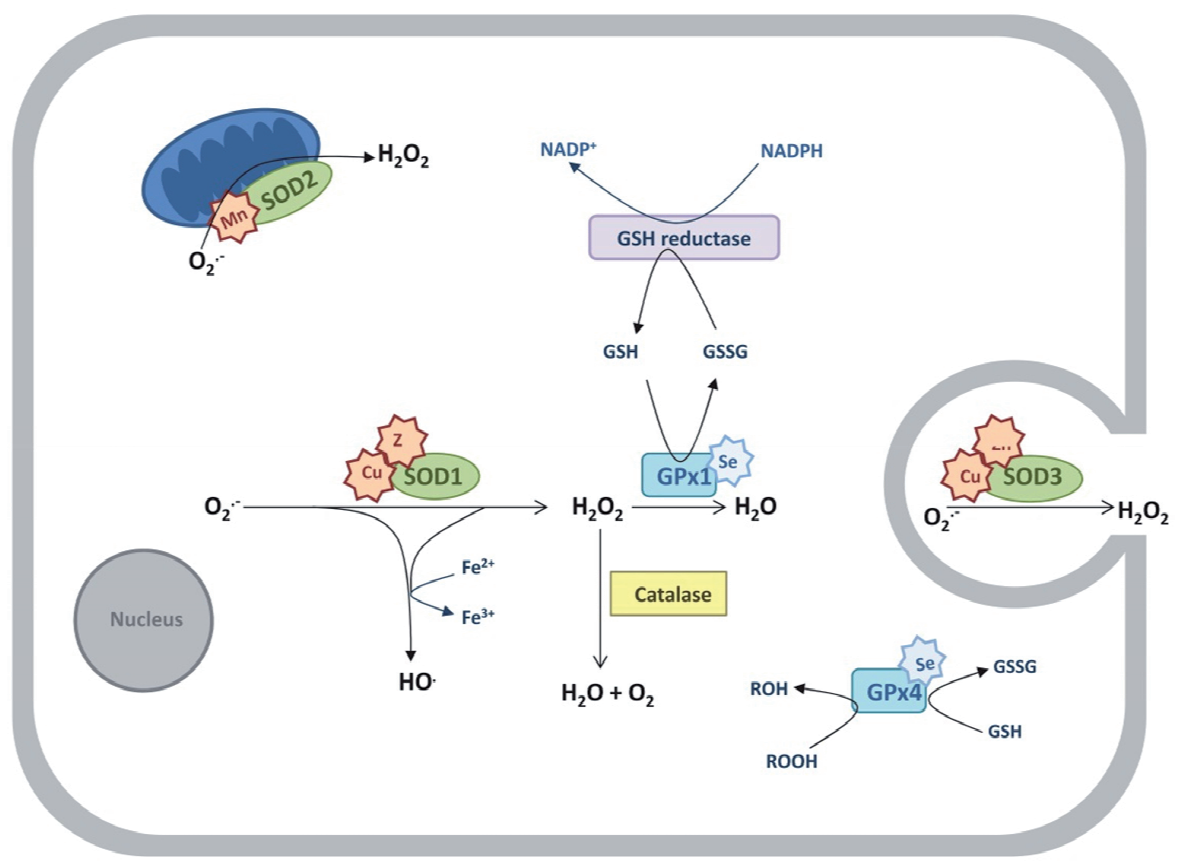

Figure 2. Major antioxidant enzyme defenses

Hypertensive patients have reduced activity and decreased content of antioxidant enzymes, including SOD, GPx, and catalase [43]. However, several studies have also described an adaptive increase in antioxidant enzyme activities in some experimental models of hypertension [50, 111, 112]. The uncoordinated activity of antioxidant enzymes may aggravate oxidative stress. For example, the increased dismutation of $\mathrm{O}_{2}-$ by SOD significantly increases $\mathrm{H}_{2} \mathrm{O}_{2}$ concentration, and may lead to deleterious consequences for the tissue in the absence of compensation of catalase and GPx activities [113]. Examples of altered antioxidant defenses in human and experimental hypertension are shown in Table 3 and Table 4, respectively.

\begin{tabular}{|l|l|l|l|l|}
\hline Biomarker & $\begin{array}{l}\text { Evaluated } \\
\text { in: }\end{array}$ & Alteration & Hypertension Model & Reference \\
\hline SOD & Brain & $\begin{array}{l}\downarrow \text { expression and activity of } \\
\text { Mn-SOD } \\
\downarrow \text { Cu, Zn-SOD activity } \\
\begin{array}{l}\downarrow \text { expression and activity of } \\
\text { SOD1 and SOD2 }\end{array}\end{array}$ & $\begin{array}{l}\text { Spontaneously hypertensive rats } \\
\text { (SHR) } \\
\text { Stroke prone spontaneously } \\
\text { hypertensive rats (SHRSP) }\end{array}$ & {$[114]$} \\
SHR & {$[115]$} \\
\hline
\end{tabular}




\begin{tabular}{|c|c|c|c|c|}
\hline Biomarker & $\begin{array}{l}\text { Evaluated } \\
\text { in: }\end{array}$ & Alteration & Hypertension Model & Reference \\
\hline & Kidney & $\begin{array}{l}\downarrow \text { expression of EC-SOD } \\
\uparrow \text { SOD activity } \\
\downarrow \text { expression of SOD1 and } \\
\text { SOD3 }\end{array}$ & $\begin{array}{l}\text { SHR } \\
\text { Angiotensin II (Ang II) induced } \\
\text { hypertension } \\
\text { SHR }\end{array}$ & $\begin{array}{l}{[117]} \\
{[49]} \\
{[118]}\end{array}$ \\
\hline & Arteries & $\begin{array}{l}\uparrow \text { SOD activity } \\
\downarrow \text { SOD activity } \\
\uparrow \text { expression and activity of } \\
\mathrm{Cu}, \mathrm{Zn}-\mathrm{SOD} \text { and Mn-SOD }\end{array}$ & $\begin{array}{l}\text { Hypertension induced by renin- } \\
\text { angiotensin system (RAS) activation } \\
\text { SHR } \\
\text { SHR }\end{array}$ & {$\left[\begin{array}{l}{[50]} \\
{[119,120]} \\
{[121]}\end{array}\right.$} \\
\hline \multirow[t]{3}{*}{ Catalase } & Brain & $\begin{array}{l}\downarrow \text { Catalase expression and } \\
\text { activity } \\
\downarrow \text { Catalase activity }\end{array}$ & $\begin{array}{l}\text { SHR } \\
\text { Renovascular hypertensive rat; SHR }\end{array}$ & {$\left[\begin{array}{l}{[116]} \\
{[122,123]}\end{array}\right.$} \\
\hline & Kidney & $\begin{array}{l}\uparrow \text { Catalase activity } \\
\downarrow \text { Catalase expression } \\
\uparrow \text { Catalase expression }\end{array}$ & $\begin{array}{l}\text { SHR; Ang II-induced hypertension; } \\
\text { SHR } \\
\text { SHR }\end{array}$ & $\begin{array}{l}{[49,122]} \\
{[124]} \\
{[125]}\end{array}$ \\
\hline & Arteries & $\begin{array}{l}\uparrow \text { Catalase activity } \\
\downarrow \text { Catalase activity }\end{array}$ & $\begin{array}{l}\text { Hypertension induced by RAS } \\
\text { activation } \\
\text { SHR }\end{array}$ & {$\left[\begin{array}{l}{[50]} \\
{[120]}\end{array}\right.$} \\
\hline \multirow[t]{4}{*}{ GPx } & Brain & $\downarrow$ GPx activity & SHR & [122] \\
\hline & Kidney & $\begin{array}{l}\uparrow \text { GPx activity } \\
\downarrow \text { GPx expression } \\
\downarrow \text { GPx activity }\end{array}$ & $\begin{array}{l}\text { Ang II-induced hypertension } \\
\text { SHR } \\
\text { SHR }\end{array}$ & $\begin{array}{l}{[49]} \\
{[124,125]} \\
{[122]}\end{array}$ \\
\hline & Arteries & $\begin{array}{l}\uparrow \text { GPx activity } \\
\downarrow \text { GPx activity }\end{array}$ & $\begin{array}{l}\text { Hypertension induced by RAS } \\
\text { activation } \\
\text { SHR }\end{array}$ & {$\left[\begin{array}{l}{[50]} \\
{[120]}\end{array}\right.$} \\
\hline & & $\downarrow$ GPx expression & $\begin{array}{l}\text { Salt- sensitive hypertension } \\
\text { (Ovariectomized female rats) }\end{array}$ & [126] \\
\hline
\end{tabular}

Table 4. Alterations in major antioxidant enzyme defenses in the brain, kidney and arteries in experimental models of hypertension 


\subsection{Non-enzymatic antioxidants defenses}

Non-enzymatic antioxidants such as GSH, ascorbic acid (vitamin C) and $\alpha$-tocopherol (vitamin E) play an excellent role in protecting the cells from oxidative damage [4]. GSH has a potent electron-donating capacity that renders GSH both a potent antioxidant per se and a conventional cofactor for enzymatic reactions that require readily available electron pairs. In physiological conditions, GSH is present inside the cells mainly in its reduced form and less than 10 percent of total GSH exists in the oxidized form, GSSG [127]. Therefore, intracellular GSH status can be used as a sensitive marker of the cell health and resistance to toxicity. Furthermore, it has been demonstrated that GSH depletion can lead to cell apoptosis [128]. The measurements of GSH and GSSG have been considered useful indicators of the status of oxidative stress [4, 129]. Vitamins $\mathrm{E}$ and $\mathrm{C}$ are among the major dietary antioxidants. The vitamins have received considerable attention in clinical trials of primary and secondary prevention of cardiovascular diseases (CVD) and cancer. Vitamin E is found in lipoproteins, cell membranes and extracellular fluids. It terminates lipid peroxidation processes and converts $\mathrm{O}_{2}$-and $\mathrm{HO}$ to less reactive forms [130]. Vitamin C, a water soluble antioxidant, is found in high concentrations in the adrenal and pituitary glands, liver, brain, spleen and pancreas. It is hydrophilic and can directly scavenge ROS and lipid hydroperoxides. Vitamin C can also restore oxidized vitamin E and can spare selenium [131]. Carotenoids, such as $\beta$ carotene are lipid soluble antioxidants that function as efficient scavengers of ${ }^{1} \mathrm{O}_{2}$ but may also quench ROO radicals [108]. Uric acid is a highly abundant aqueous antioxidant, considered to be the main contributor for the antioxidant capacity in the plasma $[96,132]$. It has the ability to quenche $\mathrm{HO}$ and $\mathrm{ONOO}^{-}$and may prevent lipid peroxidation [21, 132]. The scavenging of ONOO- by uric acid is significantly increased in the presence of Vitamin $\mathrm{C}$ and cysteine which regenerate the urate radical formed in these reactions. Uric acid also acts as a chelator of iron in extracellular fluids [16]. However, once inside the cells, uric acid appears to exert prooxidant effects. It is not clear whether the correlation between the raised plasma levels of uric acid and cardiovascular risk are due to increased ROS generation by $\mathrm{XO}$ or to the prooxidative effects of uric acid itself. Some authors speculate that the increased concentrations of urate might be an adaptive mechanism that confers protection from oxidative damage [132]. It is likely that uric acid effects have different consequences depending on the surrounding microenvironment [21]. Bilirrubin, the end-product of heme catabolism, also appears to function as a chainbreaking antioxidant [133]. Low circulating bilirrubin levels are considered a risk factor for cardiovascular diseases [134]. Plasma albumin, the predominant plasma protein, is also an antioxidant due to its sulfhydryl groups and is able to scavenge MPO-derived chlorinated reactive species and ROO radicals [108, 135].

The combined antioxidant activities of aqueous- and lipid-antioxidants, including GSH, vitamins, uric acid, bilirrubin, albumin, etc, can be evaluated in the plasma and serum by several assays that measure the ability of the antioxidants present in the sample to inhibit the oxidation of the cation radical $\mathrm{ABTS}^{+}$[2,2'-azino-bis(3-ethylbenzothiazoline-6-sulphonic acid] (Total Antioxidant Status assay), to reduce a ferric-tripyridyltriazine complex (Ferric Reducing Ability of Plasma, FRAP assay) or to trap free radicals (Oxygen Radical Absorbance Capacity, ORAC assay; Total radical Trapping Parameter, TRAP) [50, 136-138]. 
The measurement of the overall antioxidant capacity may be more representative of the in vivo balance between oxidizing and antioxidant compounds than the evaluation of individual antioxidants [139]. Nevertheless, these assays have also some limitations. First, they correlate poorly with each other as the various antioxidants react differently in each assay. Second, in biological fluids, uric acid appears to account for more than $50 \%$ of the total antioxidant activity measured in most assays [108]. However, the putative protective effect of uric acid is debatable [140, 141].

Under conditions of high ROS levels it is expected a decrease of non-enzymatic antioxidants defenses in plasma, since the need for neutralization ROS species implies a higher consumption of endogenous antioxidants. For example, decreased levels of antioxidant vitamins $\mathrm{C}$ and $\mathrm{E}$ have been demonstrated in newly diagnosed untreated hypertensive patients compared with normotensive control subjects [142-144].

\subsection{Systemic, urinary and tissue markers of lipid peroxidation}

Measuring oxidative stress in biological systems is complex and requires accurate quantification of ROS or damaged biomolecules. One method to quantify oxidative stress is to measure lipid peroxidation. Lipids that contain unsaturated fatty acids with more than one double bond are particularly susceptible to the action of free radicals. The peroxidation of lipids disrupts biological membranes and is thereby highly deleterious to its structure and function [145]. A large number of by-products are formed during this process and can be measured by different assays. Common biomarkers of lipid peroxidation damage include hydroperoxides, which are primary products generated in the initial stages of lipid peroxidation, and secondary products formed at later lipid peroxidation stages, such as malondialdehyde (MDA) or F2-isoprostanes (Table 5) [146, 147].The lag time required for the exponential generation of lipid peroxidation products can also be used to evaluate the susceptibility of lipid molecules to free radical damage. Therefore, lipids with higher resistance to oxidative stress exhibit longer lag times than those which are easily attacked by free radicals [147].

\subsection{F2-isoprostanes}

F2-isoprostanes are prostaglandin F2 $\alpha$ isomers primarily produced by free radical-catalyzed peroxidation of the polyunsaturated fatty acid (PUFA), arachidonic acid [97]. Although there is also evidence of F2-isoprostane formation by the action of cyclooxygenase, it is currently assumed that systemic and urinary F2-isoprostanes are mostly derived from free radical-induced lipid peroxidation, independently of cyclooxygenase enzymatic activity. Therefore, F2-isoprostanes have been regarded as reliable biomarkers of oxidative stress. Furthermore, F2-isoprostanes have been shown to exert potent vasoconstrictor effects on animal and human vessels, suggesting a pathogenic role in cardiovascular diseases and have been extensively used as markers of lipid peroxidation in human diseases [74, 75,148]. Their high stability and presence in measurable concentrations in many biological tissues and fluids, under physiological and pathological conditions, has also allowed the establishment of reference intervals and the comparison or monitoring of disease states 
$[97,149,150]$. Urine specimens are particularly suited for F2-isoprostanes measurements. First, the ex vivo formation of F2 isoprostanes is minimized in these samples due to the low urinary lipid content, avoiding the need for time-sensitive sample processing [97, 149, 151, 152]. Second, they provide a noninvasive route for systemic oxidative stress evaluation. Although they can also be locally produced in the kidney, many studies have demonstrated that urinary F2-isoprostanes are mainly derived from free F2-isoprostanes filtered from the circulation [97, 149, 151, 152]. Only hydrolyzed isoprostanes are excreted into the urine whereas blood plasma samples contain both free and esterified isoprostanes. Since plasma samples have considerable amounts of arachidonic acid, the addition of preservatives, such as butylated hydroxytoluene (BHT) and indomethacin, and the storage at $-80^{\circ} \mathrm{C}$, are recommended to avoid degradation and/or ex vivo formation of F2-isoprostanes [ 97.

\subsection{TBARS}

The free radical attack to PUFAs in cellular membranes leads to the disruption of cell structure and function. MDA, one of the end products of these oxidative reactions, can be detected in several biological fluids and tissues and is therefore used as a biomarker of lipid peroxidation and oxidative stress [153]. High MDA levels indicate a high rate of lipid peroxidation [154]. The reaction of MDA with 2-thiobarbituric acid (TBA) is frequently used to estimate oxidative stress [155]. MDA reacts with TBA under conditions of high temperature and acidity generating 2-thiobarbituric acid reactive substances (TBARS) that can be measured either spectrophotometrically or spectrofluorometrically. However, these products can also be formed by sample autooxidation under assay conditions or by cross-reactivity with non-MDA substrates such as bile pigments, proteins, carbohydrates and other aldehydes. Therefore, TBARS measurements often originate doubts due to their limited specificity as markers of lipid peroxidation [156]. Nevertheless, undesirable autooxidation and non-MDA substrates reactivity can be minimized by adding BHT during sample preparation. Plasma TBARS measurements have been reported to correlate with some clinical features of cardiovascular disease, preeclampsia, ischemia/reperfusion, chronic kidney disease and cerebrovascular disorders [157-160]. Since the TBARS assay may overestimate MDA, other methods can be used to evaluate lipid peroxidation products, such as the lipid hydroperoxide (LPO) test. The principle of the LPO test is that in the presence of hemoglobin, lipid hydroperoxides are reduced to hydroxyl derivates with the equimolar production of a methylene blue product, which can be quantified spectrophotometrically [161].

\subsection{HNE}

The aldehyde 4-hydroxy-2-nonenal (4-HNE) is one of the most cytotoxic products of free radical attack on $\omega 6$-PUFA, namely arachidonic and linoleic acids, being able to react with diverse biological molecules such as proteins, peptides, phospholipids and nucleic acids. It also acts as an important mediator of oxidant-induced signaling, cellular proliferation and apoptosis [97, 162]. 4-HNE can be detected in plasma and several biological tissues under physiological conditions but its generation is significantly raised in pathological states associated with oxidative stress [97, 162-164]. Renovascular hypertensive rats showed 
increased 4-HNE deposition in the intima of injured mesenteric arteries, suggesting the presence of free radical injury and cytotoxicity induced by 4-HNE [163]. A wide diversity of effects have been demonstrated for 4-HNE depending on its concentration. Concentrations below 0.1 microM are within the physiological range and appear to induce chemotaxis and stimulation of guanylate cyclase and phospholipase C [165]. 4-HNE concentrations between 1-20 microM inhibit DNA and protein synthesis and stimulate phospholipase A2. Higher concentrations (100 microM and above) are cytotoxic and genotoxic leading to cell death [165]. Thus, 4-HNE represents a broad indicator of lipid peroxidation.

\subsection{Early stage of lipid peroxidation products}

Lipid hydroperoxides are the primary products of lipid peroxidation and can further react to form secondary products including aldehydes such as MDA and 4-HNE [166,167]. Therefore, lipid hydroperoxides may be used to evaluate initial stage or acute lipid peroxidation while MDA and 4-HNE appear to be more representative of chronic oxidative stress. Recent reports described that 13-hydroperoxyoctadecadienoic acid (13-HPODE), a precursor to 3-hydroxyoctadecadienoic acid (13-HODE) is able to react with proteins forming adducts by covalently binding to specific amino acid residues. The HexanoylLysine (HEL) adduct results from the oxidative modification of $\omega 6$-PUFAs such as linoleic acid, the predominant PUFA in the human diet, and arachidonic acid [168]. HEL may be another useful biomarker for detecting and quantifying the earlier stages of lipid peroxidation. Monoclonal antibodies and ELISA kits have been developped, and HEL can be detected in oxidatively modified LDL, in human atherosclerotic lesions, human urine and serum. It has been also reported that HEL is formed in rat muscle during exercise and that its formation is inhibited by antioxidants such as flavonoids [169].

The lipid peroxidation biomarkers most commonly evaluated in hypertensive patients or experimental hypertension are shown in Table 3 and Table 5, respectively.

\begin{tabular}{|c|c|c|c|c|}
\hline $\begin{array}{l}\text { Lipid peroxidation } \\
\text { biomarker }\end{array}$ & Measured in: & Alteration & $\begin{array}{l}\text { Experimental model of } \\
\text { hypertension }\end{array}$ & References \\
\hline MDA & $\begin{array}{l}\text { Plasma } \\
\text { Aorta } \\
\end{array}$ & $\uparrow$ & $\begin{array}{l}\text { SHR } \\
\text { Salt-loaded SHR }\end{array}$ & $\begin{array}{l}{[170]} \\
{[94]}\end{array}$ \\
\hline TBARS & $\begin{array}{l}\text { Plasma } \\
\text { Plasma } \\
\text { Plasma, Heart } \\
\text { Urine } \\
\text { Aorta, Left Ventricle }\end{array}$ & $\uparrow$ & $\begin{array}{l}\text { Hypertension induced by RAS } \\
\text { activation } \\
\text { Ang II-induced hypertension } \\
\text { Mineralocorticoid-induced } \\
\text { hypertension } \\
\text { Salt-sensitive hypertension } \\
\text { Ang II-induced hypertension }\end{array}$ & {$\left[\begin{array}{l}{[50]} \\
{[171]} \\
{[172]} \\
{[173]} \\
{[174]}\end{array}\right.$} \\
\hline
\end{tabular}




\begin{tabular}{|c|c|c|c|c|}
\hline $\begin{array}{l}\text { Lipid peroxidation } \\
\text { biomarker }\end{array}$ & Measured in: & Alteration & $\begin{array}{l}\text { Experimental model of } \\
\text { hypertension }\end{array}$ & References \\
\hline F2-Isoprostanes & $\begin{array}{l}\text { Plasma } \\
\text { Plasma } \\
\text { Urine }\end{array}$ & $\mid \uparrow$ & $\begin{array}{l}\text { Salt-sensitive hypertension } \\
\text { Glucocorticoid-induced } \\
\text { hypertension } \\
\text { SHR }\end{array}$ & $\mid \begin{array}{l}{[175]} \\
{[87]} \\
{[170,176]}\end{array}$ \\
\hline 4-HNE & $\begin{array}{l}\text { Mesenteric arteries } \\
\text { Aorta }\end{array}$ & $\uparrow$ & $\begin{array}{l}\text { Renovascular hypertension } \\
\text { SHRSP }\end{array}$ & {$[163]$} \\
\hline 4-HNE adducts & Blood & $\uparrow$ & SHR & {$[178]$} \\
\hline
\end{tabular}

Table 5. Lipid peroxidation biomarkers in experimental hypertension

\subsection{Other prooxidant biomarkers}

Besides antioxidants and lipid peroxidation parameters, there are other important indexes of oxidant status. These include the expression and activity of prooxidant enzymes, ROS concentration, byproducts formed by ROS/RNS interaction with DNA (8-hydroxy-2deoxyguanosine) or proteins (3-nitrotyrosine, carbonyl groups) and redox-sensitive transcription factors such as nuclear factor kappa B (NF-KB). Major sources of cellular ROS include Nox enzymes, mitochondrial electron transport enzymes, uncoupled NOS, XO and MPO. Table 6 summarizes several prooxidant biomarkers evaluated in experimental models of hypertension.

\begin{tabular}{|c|c|c|c|c|}
\hline $\begin{array}{c}\text { Biomarkers of } \\
\text { prooxidant status }\end{array}$ & Evaluated in: & Alteration & Hypertension model & Reference \\
\hline \multirow{2}{*}{$\begin{array}{l}\text { Mitochondrial electron } \\
\text { transport chain } \\
\text { enzymes/ } \\
\text { mitochondrial ROS } \\
\text { production }\end{array}$} & Brain & $\begin{array}{l}\text { Oxidative impairment } \\
\text { of mitochondrial } \\
\text { enzymes }\end{array}$ & SHR & {$[30]$} \\
\hline & Kidney & $\begin{array}{l}\uparrow \text { mitochondrial ROS } \\
\text { production }\end{array}$ & $\begin{array}{l}\text { SHR, Mineralocorticoid } \\
\text { hypertension }\end{array}$ & {$[179,180]$} \\
\hline \multirow{4}{*}{$\begin{array}{l}\text { NADPH oxidase } \\
\text { family enzymes (or } \\
\text { NOXs) }\end{array}$} & Brain & $\begin{array}{l}\uparrow \text { NADPH oxidase } \\
\text { activity }\end{array}$ & Salt-loaded SHRSP & {$[181]$} \\
\hline & Kidney & $\begin{array}{l}\uparrow \text { Nox4 expression, } \uparrow \\
\text { NADPH oxidase } \\
\text { activity }\end{array}$ & $\begin{array}{l}\text { Ang II-induced } \\
\text { hypertension }\end{array}$ & [49] \\
\hline & Arteries & $\begin{array}{l}\uparrow \text { expression of } \\
\text { NAD(P)H oxidase } \\
\text { subunits (p67(phox) } \\
\text { and gp91(phox) }\end{array}$ & $\begin{array}{l}\text { Ang II-induced } \\
\text { hypertension }\end{array}$ & [182] \\
\hline & & $\begin{array}{l}\uparrow \text { Nox1 and Nox4 } \\
\text { expression }\end{array}$ & SHRSP & {$[183]$} \\
\hline
\end{tabular}




\begin{tabular}{|c|c|c|c|c|}
\hline $\begin{array}{c}\text { Biomarkers of } \\
\text { prooxidant status }\end{array}$ & Evaluated in: & Alteration & Hypertension model & Reference \\
\hline & & $\begin{array}{l}\uparrow \text { NADPH oxidase } \\
\text { activity }\end{array}$ & $\begin{array}{l}\text { Ang II-induced } \\
\text { hypertension; } \\
\text { Hypertension induced by } \\
\text { RAS activation }\end{array}$ & \begin{tabular}{|l}
{$[50,184-$} \\
$186] 1$
\end{tabular} \\
\hline eNOS & Arteries & $\begin{array}{l}\text { Uncoupled eNOS/ } \uparrow \\
\text { eNOS-derived ROS }\end{array}$ & SHR & [34] \\
\hline & Arteries & $\begin{array}{l}\uparrow \text { eNOS expression } / \downarrow \\
\text { eNOS activity }\end{array}$ & SHR & {$[35]$} \\
\hline $\mathrm{XO}$ & $\begin{array}{l}\text { Arteries } \\
\text { Arteries }\end{array}$ & $\begin{array}{l}\uparrow \mathrm{XO} \text { activity } \\
\uparrow \mathrm{XO} \text { expression }\end{array}$ & $\begin{array}{l}\text { SHR } \\
\text { SHR }\end{array}$ & {$\left[\begin{array}{l}{[187]} \\
{[188]}\end{array}\right.$} \\
\hline $\mathrm{H}_{2} \mathrm{O}_{2}$ & $\begin{array}{l}\text { Kidney, Blood } \\
\text { /urine }\end{array}$ & $\begin{array}{l}\text { 个 renal production } / \uparrow \\
\text { production in plasma } \\
/ \uparrow \text { urinary excretion } \\
\end{array}$ & $\begin{array}{l}\text { Ang II-induced } \\
\text { hypertension }\end{array}$ & [49] \\
\hline $\mathrm{MPO}$ & \begin{tabular}{|l|} 
Arteries \\
Kidney, Heart, \\
Brain
\end{tabular} & $\begin{array}{l}\uparrow \mathrm{MPO} \text { activity } \\
\uparrow \mathrm{MPO} \text { activity }\end{array}$ & $\begin{array}{l}\text { SHRSP } \\
\text { Renovascular } \\
\text { hypertension }\end{array}$ & $\begin{array}{l}{[189]} \\
{[190]}\end{array}$ \\
\hline GSH/GSSG & $\begin{array}{l}\text { Kidney } \\
\text { Plasma, Heart, } \\
\text { kidney }\end{array}$ & $\begin{array}{l}\downarrow \text { ratio } \\
\downarrow \text { ratio }\end{array}$ & $\begin{array}{l}\text { SHR } \\
\text { Salt-sensitive } \\
\text { hypertension }\end{array}$ & {$\left[\begin{array}{l}{[191]} \\
{[192]}\end{array}\right.$} \\
\hline 3-nitrotyrosine & Kidney & $\uparrow$ expression & SHR & [193] \\
\hline $\begin{array}{l}\text { Protein carbonyl } \\
\text { groups }\end{array}$ & $\begin{array}{l}\text { Arteries, Heart, } \\
\text { Kidney } \\
\text { Kidney }\end{array}$ & $\begin{array}{l}\uparrow \text { expression } \\
\uparrow \text { expression }\end{array}$ & $\begin{array}{l}\text { SHR } \\
\text { SHR }\end{array}$ & {$\left[\begin{array}{l}{[194]} \\
{[195]}\end{array}\right.$} \\
\hline $\begin{array}{l}\text { 8-Hydroxy-2- } \\
\text { deoxyguanosine } \\
\text { (8-OH-dG) }\end{array}$ & $\begin{array}{l}\text { Arteries, Heart, } \\
\text { Kidney, }\end{array}$ & $\uparrow$ expression & SHR & [194]. \\
\hline NF- $\kappa B$ & $\begin{array}{l}\text { Kidney } \\
\text { Arteries }\end{array}$ & $\begin{array}{l}\uparrow \text { activation } \\
\uparrow \text { activation }\end{array}$ & $\begin{array}{l}\begin{array}{l}\text { SHR; Ang II-induced } \\
\text { hypertension }\end{array} \\
\text { Ang II-induced } \\
\text { hypertension }\end{array}$ & $\begin{array}{l}{[49,196]} \\
{[197]}\end{array}$ \\
\hline
\end{tabular}

Table 6. Other Prooxidant status biomarkers in experimental hypertension

\section{Prophylactic and therapeutic strategies to reduce oxidative damage in arterial hypertension}

A plethora of studies has demonstrated that hypertension is associated with an imbalance between oxidants and antioxidants that leads to altered cell signaling and oxidative damage. 
Therefore, extensive research has been conducted in order to identify the ROS involved in blood pressure dysregulation, as well as the major prooxidant enzymes and antioxidant defenses that contribute to the loss of redox homeostasis in cardiovascular and renal systems. Furthermore, studies on experimental models of hypertension recognized several important neurohumoral stimuli responsible for ROS overproduction and also the main targets for ROS-induced dysfunction [8,43]. Therapeutic interventions to reduce oxidative stress in hypertension have mostly relied on the administration of drugs that increase antioxidant capacity or inhibit ROS generation. In addition, other strategies aimed at reducing the activation of neurohumoral pathways that stimulate ROS production (upstream mediators) or at blocking/repairing the downstream targets affected by ROS have also been tested [196, 198, 199].

\subsection{Targeting oxidative stress in experimental hypertension}

The pharmacological modulation of ROS bioavailability in animal models of hypertension has been useful to demonstrate a causative role for oxidative stress in the pathophysiology of hypertension $[43,50]$. However, the blood pressure lowering efficacy of these strategies appears to differ when comparing distinct experimental models [48, 50, 85, 200, 201]. This is probably because the development of each animal model was based on a particular etiological factor presumably responsible for human hypertension, such as high salt intake, overactivation of the renin-angiotensin system, genetic factors or renal disease. Since these factors may stimulate different redox pathways, the effectiveness of an antioxidant in one model does not necessarily translate to other models or to human essential hypertension which is known to have a multifactorial nature. Another important observation is that treatments with antioxidants or ROS inhibitors are generally more effective in preventing rather than reversing the hypertension [49, 50, 87, 202]. Indeed, there are several studies demonstrating that ROS activate feed-forward mechanisms that amplify the cardiovascular and renal dysfunction [8, 43, 49,51]. Once triggered, these pathways may be sufficient to sustain the deleterious effects of oxidative stress even after ROS blockade or elimination [49]. In vivo drug treatments targeting oxidative stress in experimental models of hypertension are reviewed below and their effects on blood pressure are summarized in Table 7.

\subsubsection{Drugs inhibiting ROS production}

Apocynin is a methoxy-substituted catechol (4-hydroxy-3-methoxy-acetophenone), originally extracted from the roots of the tradicional medicinal herb Picrorhiza kurroa which has antiinflammatory properties [203]. Several experimental studies have used apocynin for its ability to inhibit Nox enzymes. The mechanism of inhibition involves the blockade of translocation of cytosolic protein subunits to the membrane which is crucial for the activation of Nox1 and Nox2 [204]. Thus, the effect of apocynin is restricted to inducible Nox enzymes that require cytosolic activators and it does not seem to affect constitutively active Nox isoforms and their putative physiological actions [204]. However, to be an effective Nox inhibitor, apocynin has to undergo a peroxidase-mediated oxidation to be converted into the metabolically active 
diapocynin [205-207]. The activation of apocynin occurs in the presence of $\mathrm{MPO}$ and $\mathrm{H}_{2} \mathrm{O}_{2}$ $[205,207]$. This fact suggests that apocynin may function only in conditions of high inflammatory and prooxidant activity. Apocynin has also been shown to have direct antioxidant properties, being able to scavenge $\mathrm{H}_{2} \mathrm{O}_{2}$ derived products [205, 207]. However, it can also function as a prooxidant in resting cells [203]. Nevertheless, it is possible that when administered in conditions of enhanced oxidative stress, the protective effect prevails.

Gp91ds-tat is a chimeric peptide that specifically inhibits NADPH oxidase by preventing the assembly of its subunits. It is constituted by a segment of gp91phox (gp91ds) important for the interaction of this membrane subunit with the cytosolic subunit, $\mathrm{p} 47 \mathrm{phox}$, and by a tat peptide from the HIV virus, which allows the uptake of the peptide into the cell [208, 209]. However, since it is a peptide it may have poor oral bioavailability and may induce sensitization reactions. Furthermore, the tat segment may have side effects on cellular signaling and activity [204, 208]. Thus, it is not suitable for long treatments or to clinical use in the treatment of human cardiovascular diseases. Although it was designed to block Nox2, it may also inhibit Nox1 given the substantial degree of homology between the two isoforms [204]. As for apocynin, Nox4 is not likely to be affected by gp91ds-tat since it is constitutively active and does not require the activation of cytosolic subunits [204].

Allopurinol and its metabolite oxypurinol are hypoxanthine and xanthine analogs, respectively, that inhibit $\mathrm{XO}$ activity [16]. At low concentrations, allopurinol is a competitive inhibitor of $\mathrm{XO}$, while at higher concentrations it behaves as a non-competitive inhibitor [16]. XO rapidly metabolizes allopurinol into oxypurinol, a noncompetitive inhibitor of the enzyme which has a much higher half-life and is therefore responsible for most of the pharmacological effects of allopurinol [16]. In addition, both allopurinol and oxypurinol have intrinsic antioxidant properties, being able to scavenge $\mathrm{ROS}$ such as $\mathrm{O}_{2-}^{-}, \mathrm{HO}$ and $\mathrm{HClO}$ [210-212]. However, these effects appear to require higher doses than those required for XO inhibition [210]. Allopurinol is approved for the treatment of human patients with gout or hyperuricemia, but it has also potential therapeutic application in cardiovascular diseases. Most common adverse effects are nauseas, diarrheas, hypersensitivity reactions and skin rash [16].

\subsubsection{Antioxidants}

Tempol (4-hydroxy-2,2,6,6-tetramethylpiperidine-1-oxyl) is a membrane-permeable nitroxide that catalyzes the conversion of $\mathrm{O}_{2}-$ to $\mathrm{H}_{2} \mathrm{O}_{2}$ thus functioning as a SOD mimetic $[213,214]$. Tempol protects the lipids or proteins from oxidative damage and interacts with other antioxidants to promote the reduction of oxidized lipids [214]. The main antihypertensive effect of this drug is related to the reduction of the $\mathrm{O}_{2}$ - interaction with $\mathrm{NO}$ which improves vasodilation [213, 214]. It also promotes natriuresis by enhancing the vasodilation of renal medullary vessels in a $\mathrm{NO}$ independent manner [214]. Indeed, tempol has been shown to have sympatholytic actions, being able to inhibit afferent, peripheral and central activation of the sympathetic nervous system [214]. These actions are responsible for the rapid fall of blood pressure and heart rate after acute intravenous administration of tempol [214]. Nevertheless, some studies reported that the formation of $\mathrm{H}_{2} \mathrm{O}_{2}$ by tempol can 
counteract its vasodilator, natriuretic and antihypertensive effects in models of hypertension where $\mathrm{H}_{2} \mathrm{O}_{2}$ plays a more prominent role than $\mathrm{O}_{2}^{-}[48,50,53]$. The co-administration of catalase in these conditions restores the protective action of tempol $[48,50]$.

$\mathrm{N}$-acetylcysteine (NAC) is a thiol containing compound. It is the acetylated derivative of the aminoacid L-cysteine and a precursor for reduced glutathione (GSH) [215, 216]. It appears to have direct antioxidant action since its free thiol can interact with the electrophilic groups of ROS [215]. However, this effect does not seem likely to occur in vivo because NAC has poor oral bioavailability being rapidly metabolized into GSH, among other metabolites [216]. Thus, the main protective action of NAC is probably related to its role as a GSH precursor, which then detoxifies reactive species either by enzymatic or non-enzymatic reactions [216]. In humans, NAC is approved as a mucolytic agent because it destroys the disulphide bridges of mucoproteins [215]. It is also used as an antidote for acetaminophen poisoning which dramatically depletes hepatic GSH content causing severe damage [217]. NAC may also have potential therapeutical applications in the treatment of heart diseases [218].

Polyethylene glycol-catalase is the conjugated form of the enzyme catalase with polyethylene glycol (PEG) which enhances the stability in aqueous solution, reduces immunogenicity and decreases sensitivity to proteolysis, thus increasing the circulatory half-life of catalase [219]. PEG also enhances the catalase association with cells [219]. The antioxidant effect of PEG-catalase results from the enzymatic degradation of $\mathrm{H}_{2} \mathrm{O}_{2}$ to water.

Ebselen (2-phenyl-1,2-benzisoselenazol-3[2H]-one) is a lipid-soluble seleno-organic compound that mimics glutathione peroxidase activity, being able to react with $\mathrm{H}_{2} \mathrm{O}_{2}$ and organic hydroperoxides including membrane-bound phospholipid and cholesterylester hydroperoxides [220]. It appears to reduce lipid peroxidation initiated by hydroperoxides but not free radicals initiators [221]. In addition, ebselen reacts rapidly with ONOO. The ebselen selenoxid product yielded in this reaction is regenerated to ebselen by GSH, which allows its reutilization as a defense against $\mathrm{ONOO}^{-}[222,223]$. Ebselen also directly inhibits inflammation-related enzymes such as 5-lipoxygenase, $\mathrm{NO}$ synthases, protein kinase $\mathrm{C}$, NADPH oxidase and $\mathrm{H}^{+} / \mathrm{K}^{+}$-ATPase by reacting with the $\mathrm{SH}$ group, leading to the formation of a selenosulphide complex [221]. Some authors have also proposed that the antioxidant and anti-inflammatory actions of ebselen are mediated through interactions with the thioredoxin (Trx) system [220]. Reduced Trx is important for growth and redox regulation by thiol redox control [220]. Ebselen was found to be an excellent substrate for mammalian TrxR and a highly efficient oxidant of reduced Trx. It also seems to function as a Trx peroxidase or peroxiredoxin mimic, thus contributing to the elimination of $\mathrm{H}_{2} \mathrm{O}_{2}$ and lipid hydroperoxides [220]. Ebselen has been used in clinical trials for the treatment of patients with acute ischemic stroke or delayed neurological deficit after aneurismal subarachnoid hemorrhage [224, 225].

Vitamin C (ascorbic acid) is a water soluble antioxidant found in the body as an ascorbate anion. It acts as a free radical scavenger [226]. Although this effect requires higher concentrations than those achieved in the plasma by oral administration, ascorbate appears to concentrate in tissues in much higher levels than those found in the plasma and can act effectively as a ROS scavenger [227]. In addition, it reduces membrane lipid peroxidation 
and regenerates Vitamin E [226]. Recent reports also suggest that Vitamin C can suppress NADPH oxidase activity [227].

Vitamin $\mathbf{E}$ is a generic term for a group of compounds including tocopherols and tocotrienols. The isoform $\alpha$-tocopherol appears to be the most abundant in vivo [227]. Vitamin E terminates the propagation of the free radical chain reaction in lipid membranes and inhibits LDL oxidation [226, 227]. Vitamin E can also have non antioxidant actions primarily through the regulation of enzymes involved in signal transduction. Enzymes inhibited by vitamin $\mathrm{E}$ include protein kinases $\mathrm{C}$ and $\mathrm{B}$, protein tyrosine kinase, lipoxygenases, mitogen activated protein kinases, phospholipase A2 and cyclooxygenase- 2 . In contrast, vitamin $\mathrm{E}$ has stimulatory effects on protein tyrosine phosphatase and diacylglycerol kinase [228]. Both vitamins $C$ and $E$ have been shown to stimulate the activation of NOS activity and increase $\mathrm{NO}$ synthesis in endothelial cells and thus may contribute to improved endothelial-dependent vasodilation in hypertension [229]. However, although Vitamins $\mathrm{C}$ and $\mathrm{E}$ are generally considered to be non-toxic, they can undergo oxidation and generate pro-oxidant molecules [226]. Nevertheless, it appears that this is more likely to occur with Vitamin E, especially in the absence of sufficient Vitamin C to regenerate the $\alpha$-tocopherol radical $[227,230,231]$.

Alpha-lipoic acid (1,2-dithiolane-3-pentanoic acid or thioctic acid) has a wide range of effects on cell functions, acting as an antioxidant, a metal chelator and a signaling mediator [232]. Both lipoic acid (LA) and its reduced form dihydrolipoic acid (DHLA), may scavenge $\mathrm{HO}$ and $\mathrm{HClO}$, although neither species is able to neutralize $\mathrm{H}_{2} \mathrm{O}_{2}$ [232]. DHLA also regenerates Vitamins $\mathrm{C}$ and $\mathrm{E}$ and does not become a free radical after reacting with these species. Furthermore, LA and DHLA chelate transition metals, thus reducing the metalcatalyzed free radical damage [232]. LA also contributes to improve antioxidant defenses by increasing the intracellular levels of Vitamin C and GSH. Many of LA protective actions have been attributed to its interference in cell signaling processes [232]. For example, LA effect on GSH appears to be mediated by nuclear factor erythroid 2- related factor 2 (Nrf2), an important transcription factor regulating gene transcription through the Antioxidant Response Element. LA was also shown to interact with several kinases and protein phosphatases [232]. Its interaction with components of the insulin signaling cascade also appears to improve glucose disposal in animal models of diabetes and human diabetic patients [232]. In addition, LA improves endothelial $\mathrm{NO}$ synthesis and endothelialdependent vasodilation and prevents deleterious modifications of thiol groups in $\mathrm{Ca}^{2+}$ channels [232]. It has also important anti-inflammatory effects by inhibiting the activation of NF-KB, a transcription factor that regulates the expression of proinflammatory genes [232].

Pyrrolidine dithiocarbamate (PDTC), a low-molecular weight thiol compound, has the ability to scavenge oxygen radicals and to chelate metals [233, 234]. It may also act as a prooxidant and a thiol group modulator [233]. PDTC has been shown to interfere with the activation of several transcription factors, being a potent inhibitor of NF-KB [233, 234]. PDTC can also activate other signaling pathways, such as the extracellular signal-regulated kinase (ERK), c-Jun N-terminal kinase (JNK) and the transcription factor Heat Shock Factor (HSF) [233, 235]. 
$5,6,7,8$-Tetrahydrobiopterin $\left(\mathrm{BH}_{4}\right)$ is a key cofactor of NOS [236, 237]. It is involved in the formation and stabilization of eNOS and iNOS [236, 238]. In the absence of $\mathrm{BH}_{4}, \mathrm{NOS}$ can become uncoupled and starts producing $\mathrm{O}_{2} \cdot$ instead of $\cdot \mathrm{NO}[33,237]$. Furthermore, $\mathrm{BH}_{4}$ also possesses direct antioxidant activity, being able to scavenge $\mathrm{O}_{2}$ - and $\mathrm{HO}$ [239]. The protective effects of $\mathrm{BH}_{4}$ on the development of hypertension appear to be due an increase in eNOS activity, a reduction in $\mathrm{O}_{2}^{--}$production and a decrease in iNOS expression [199].

\begin{tabular}{|c|c|c|}
\hline Drug & Antihypertensive effect & Lack of antihypertensive effect \\
\hline Apocynin & $\begin{array}{l}\text { Prevented/attenuated mineralocorticoid-induced } \\
\text { hypertension [86, 240] } \\
\text { Prevented/reversed glucocorticoid-induced } \\
\text { hypertension [241] } \\
\text { Prevented/reversed adrenocorticotropic } \\
\text { hormone-induced hypertension [242] } \\
\text { Prevented the development of Ang II-induced } \\
\text { hypertension in mice [186] } \\
\text { Prevented the development of renovascular } \\
\text { hypertension [243] } \\
\text { Prevented the development of hypertension } \\
\text { induced by RAS activation [50] } \\
\text { Reduced blood pressure in borderline and } \\
\text { spontaneous hypertension [244] } \\
\text { Attenuated salt-sensitive hypertension [245] } \\
\text { Normalized blood pressure in a model of } \\
\text { hypertension induced by disruption of dopamine } \\
D_{2} \text { receptor [246] }\end{array}$ & $\begin{array}{l}\text { Failed to prevent the hypertension } \\
\text { induced by chronic infusion of } \\
\text { endothelin-1 [200] } \\
\text { Failed to prevent hypertension in } \\
\text { transgenic mice overexpressing renin } \\
\text { or angiotensinogen [247, 248] } \\
\text { Failed to prevent Ang II-induced } \\
\text { hypertension in rats [249, 250] }\end{array}$ \\
\hline Gp91ds-tat & $\begin{array}{l}\text { Attenuated the blood pressure rise induced by } \\
\text { Ang II in mice [209] }\end{array}$ & $\begin{array}{l}\text { Failed to attenuate salt-sensitive } \\
\text { hypertension [251] }\end{array}$ \\
\hline Allopurinol & $\begin{array}{l}\text { Attenuated salt-sensitive hypertension [252] } \\
\text { Prevented glucocorticoid-induced hypertension } \\
\text { [253] }\end{array}$ & $\begin{array}{l}\text { Failed to prevent or attenuate } \\
\text { mineralocorticoid-induced } \\
\text { hypertension [254] } \\
\text { Failed to prevent glucocorticoid- } \\
\text { induced hypertension [255] } \\
\text { Failed to prevent or attenuate } \\
\text { adrenocorticotropic-induced } \\
\text { hypertension [242] } \\
\text { Failed to prevent the development of } \\
\text { hypertension induced by the blockade } \\
\text { of nitric oxide synthesis [256] } \\
\text { Failed to prevent the progression of } \\
\text { hypertension in young SHR [257] }\end{array}$ \\
\hline Oxypurinol & Reduced blood pressure in SHR [258] & \\
\hline Tempol & $\begin{array}{l}\text { Attenuated hypertension in SHR [201] } \\
\text { Prevented the progression of hypertension in salt- } \\
\text { loaded SHRSP [259] } \\
\text { Attenuated mineralocorticoid-induced } \\
\text { hypertension [260] }\end{array}$ & $\begin{array}{l}\text { Failed to prevent Ang II-induced } \\
\text { hypertension [264] } \\
\text { Failed to attenuate hypertension } \\
\text { induced by inhibition of superoxide } \\
\text { dismutase [48] }\end{array}$ \\
\hline
\end{tabular}




\begin{tabular}{|c|c|c|}
\hline Drug & Antihypertensive effect & Lack of antihypertensive effect \\
\hline & $\begin{array}{l}\text { Prevented/attenuated glucocorticoid-induced } \\
\text { hypertension [87] } \\
\text { Attenuated salt-sensitive hypertension [261] } \\
\text { Prevented the development of renovascular } \\
\text { hypertension [243] } \\
\text { Attenuated high-volume hypertension [262] } \\
\text { Attenuated hypertension induced by NO } \\
\text { inhibition [112] } \\
\text { Partially prevented/reversed adrenocorticotropic } \\
\text { hormone-induced hypertension [263] }\end{array}$ & $\begin{array}{l}\text { Failed to prevent hypertension } \\
\text { induced by RAS activation [50] }\end{array}$ \\
\hline NAC & $\begin{array}{l}\text { Attenuated hypertension in young SHR [265] } \\
\text { Prevented the development of glucocorticoid- } \\
\text { induced hypertension [202] } \\
\text { Prevented the development of } \\
\text { adrenocorticotropic hormone-induced } \\
\text { hypertension [266] } \\
\text { Markedly reduced salt-sensitive hypertension [267] } \\
\text { Prevented/ attenuated hypertension induced by } \\
\text { nitric oxide synthesis inhibition [268] }\end{array}$ & $\begin{array}{l}\text { Failed to reduce blood pressure in } \\
\text { adult SHR [265] } \\
\text { Failed to attenuate glucorticoid- } \\
\text { induced hypertension [202] } \\
\text { Failed to reverse adrenocorticotropic- } \\
\text { induced hypertension [266] }\end{array}$ \\
\hline \begin{tabular}{|l|} 
PEG- \\
catalase
\end{tabular} & $\begin{array}{l}\text { Prevented the development of hypertension } \\
\text { induced by RAS activation [50] } \\
\text { Transiently decreased blood pressure in Ang II- } \\
\text { hypertensive rats [49] } \\
\text { Reduced blood pressure in high-volume } \\
\text { hypertension in mice [269] }\end{array}$ & $\begin{array}{l}\text { Lacked a sustained antihypertensive } \\
\text { effect in Ang II-induced hypertension } \\
{[49]}\end{array}$ \\
\hline Ebselen & $\begin{array}{l}\text { Attenuated the blood pressure rise induced by } \\
\text { Ang II in mice overexpressing p22phox in } \\
\text { vascular smooth muscle and in littermate control } \\
\text { mice [270] }\end{array}$ & $\begin{array}{l}\text { Failed to prevent the development of } \\
\text { hypertension induced by the blockade } \\
\text { of nitric oxide synthesis [256] }\end{array}$ \\
\hline Vitamin C & $\begin{array}{l}\text { Prevented the progression of hypertension } \\
\text { induced by salt administration in SHRSP and in } \\
\text { SHR }[229,271] \\
\text { Attenuated salt-induced hypertension }[272,273]\end{array}$ & $\begin{array}{l}\text { Failed to prevent adrenocorticotropic } \\
\text { hormone-induced hypertension [274] }\end{array}$ \\
\hline Vitamin E & $\begin{array}{l}\text { Prevented the progression of hypertension } \\
\text { induced by salt administration in SHRSP [229] } \\
\text { Attenuated hypertension in young SHRSP [275] } \\
\text { Attenuated salt-induced hypertension [273] }\end{array}$ & $\begin{array}{l}\text { Failed to prevent adrenocorticotropic } \\
\text { hormone-induced hypertension [274] }\end{array}$ \\
\hline Lipoic acid & $\begin{array}{l}\text { Reduced blood pressure in SHR [276] } \\
\text { Prevented fructose-induced hypertension [277] } \\
\text { Prevented/attenuated salt-induced hypertension } \\
{[278]} \\
\text { Prevented mineralocorticoid-induced }\end{array}$ & \\
\hline
\end{tabular}




\begin{tabular}{|c|c|c|}
\hline Drug & Antihypertensive effect & Lack of antihypertensive effect \\
\hline & hypertension [279] & \\
\hline PDTC & $\begin{array}{l}\text { Perinatal administration ameliorated } \\
\text { hypertension in SHR offsprings [280] } \\
\text { Prevented /Reduced hypertension in SHR [32, } \\
\text { 196] } \\
\text { Attenuated mineralocorticoid-induced } \\
\text { hypertension [260] }\end{array}$ & \\
\hline $\mathrm{BH}_{4}$ & $\begin{array}{l}\text { Suppressed the development of hypertension in } \\
\text { SHR [199] } \\
\text { Reduced hypertension in SHR [281] }\end{array}$ & $\begin{array}{l}\text { Failed to attenuate hypertension in } \\
\text { castrated SHR [281] } \\
\text { Failed to prevent the development of } \\
\text { adrenocorticotropic hormone in rat } \\
\text { [282] }\end{array}$ \\
\hline
\end{tabular}

Table 7. Effect of chronic treatment with antioxidants or inhibitors of ROS production on blood pressure

\subsection{Antioxidant approaches in human hypertension}

Although there is considerable evidence of oxidative stress involvement in the pathophysiology of hypertension, the attempts to demonstrate benefits from antioxidant therapy in human cardiovascular diseases have been very disappointing [5, 96, 283]. Most of the large trials regarding the effects of diet supplementation with Vitamin C, Vitamin E and $\beta$-carotene failed to show significant improvements in blood pressure and other cardiovascular endpoints [5, 283]. Furthermore, some of them also led to the conclusion that antioxidant treatment with Vitamin E or $\beta$-carotene may even be harmful [283-285]. In contrast, smaller clinical trials have provided some evidence of antioxidant treatment advantages. For example, some studies showed that systemic Vitamin C levels inversely correlates with blood pressure and that Vitamin $\mathrm{C}$ supplementation effectively attenuates hypertension [142, 286]. Vitamin E and lipoic acid have also been shown to improve vascular function, though there is not consistent evidence of a blood pressure lowering effect of these agents in human patients [5, 287, 288]. Nevertheless, it has been demonstrated that a high consumption of dietary fruits and vegetables increases plasma antioxidant capacity and reduces blood pressure $[289,290]$. Thus, it appears that a diet rich in fruits and vegetables is a better strategy than antioxidant supplementation to improve antioxidant status and cardiovascular health [5]. Overall, the clinical trials with antioxidant supplements have been very unsatisfactory and are in disagreement with the findings obtained in experimental hypertension studies. There are some possible justifications for the disappointing outcomes of these trials. First, the type of the drug used as well as the dose and duration of the therapy might not be adequate [5, 291, 292]. Most trials followed an antioxidant strategy based in the administration of ROS scavengers such as Vitamins $\mathrm{C}$ and E. However, these drugs do not neutralize $\mathrm{H}_{2} \mathrm{O}_{2}$ which has been shown to play a relevant role in the pathophysiology of hypertension and other cardiovascular diseases [5, 7, 48-50]. Furthermore, it is known that human blood and tissues have plenty antioxidants and that several stimuli induce an adaptive increase of enzymatic antioxidant defenses which can 
mask the benefits of exogenously administered antioxidants [293]. In addition, the antioxidant doses used in most of the experimental studies have been much higher than those tested in human patients [291]. So, there is the possibility that in humans the antioxidants did not achieve effective concentrations to neutralize ROS. Furthermore, it is not known if orally administered antioxidants can reach the precise sites of increased ROS production as oxidative stress is heterogeneously distributed throughout the organs, tissues and cellular compartments [5, 96, 291]. Indeed, the unspecific scavenging of ROS may even interfere with many important physiological functions in a deleterious manner [29, 96]. Another important limitation of most antioxidants tested is that they can exert themselves prooxidant effects in the absence of a coordinated antioxidant response [5,96]. For example, Vitamin E needs to be regenerated by Vitamin C otherwise it may cause oxidative damage [231].

There are also drawbacks in clinical trials design. In large trials of antioxidant supplementation, patients have not been recruited accordingly to their redox status [5, 294]. It is unlikely that a beneficial effect of antioxidant therapy would be observed in patients without previous evidence of increased oxidative stress. Another important consideration is that these clinical trials often have heterogeneous populations in terms of the etiology of cardiovascular disease [295]. Indeed, most studies have indiscriminately enrolled any patient at cardiovascular risk [294]. This is in obvious contrast to the homogeneous populations analyzed in experimental studies. Furthermore, some of the patients may be at an advanced stage of disease exhibiting irreversible damage insusceptible to antioxidant interventions $[5,29]$. It should also be highlighted that many patients enrolled in these studies were already being treated with drugs such as aspirin, lipid-lowering agents and some antihypertensive drugs which can themselves interfere with oxidant status and mask the effects of additional therapy with antioxidants [5, 92, 296, 297].

So far, most interventions aimed at reducing oxidative stress in human hypertension have relied on antioxidant supplementation. However, it is possible that a strategy based on the inhibition of ROS production is more effective than the antioxidant interventions $[5,96]$. The disruption of cardiovascular redox status is most likely triggered by an increase in prooxidant activity rather than a reduction in antioxidant defenses. Indeed, many neurohumoral or ambiental prohypertensive stimuli (angiotensin II, aldosterone, high-salt intake) are known to upregulate the expression and activity of prooxidant enzymes $[5,8$, 43]. Nevertheless, there are already some studies that investigated the cardiovascular effects of prooxidant enzyme inhibition. Patients treated with allopurinol showed improvements in vascular function [298, 299]. However, a blood pressure lowering effect of this XO inhibitor has been shown only in newly diagnosed hypertensive adolescents and in hyperuricemic patients with normal renal function [300, 301]. Furthermore, the combination of allopurinol with antihypertensive drugs did not provide additional benefits on blood pressure [299]. This is probably because $\mathrm{XO}$ is not a major contributor to the development of hypertension, even though its activity may be increased in pathophysiological conditions [5]. Indeed, compelling evidence indicates that NADPH oxidases are the main contributors to ROS overproduction in cardiovascular and renal diseases [5, 8, 302]. Moreover, Nox-derived ROS 
are known to amplify redox dysfunction by inducing the activation of other prooxidant enzymes, such as XO, mitochondrial enzymes and NOS synthases [7, 51]. Since many antihypertensive drugs block upstream activators of Nox enzymes, it is not surprising that the inhibition of $\mathrm{XO}$ by allopurinol does not improve blood pressure control in patients already treated with antihypertensive drugs. To date, no Nox inhibitors have been tested in clinical trials although some specific Nox inhibitors have already been developed and patented $[96,296]$. Future strategies to demonstrate the benefits of oxidative stress reduction in cardiovascular diseases should include the testing of specific Nox inhibitors in human patients. Moreover, the development of reliable oxidative stress biomarkers for risk stratification and monitoring of therapy is also highly desirable [96, 296]. Table 8 summarizes the possible reasons for the failure of antioxidants in clinical trials.

\begin{tabular}{|l|l|}
\hline Limitations related to the drug treatment & Limitations related to the clinical trials design \\
\hline $\begin{array}{l}\text { Inadequate dose or duration of therapy } \\
\text { Lack of effect on non-radical oxidants such as } \mathrm{H}_{2} \mathrm{O}_{2} \\
\text { Lack of effect on prooxidant activity } \\
\text { Inaccessibility of ROS scavengers to intracellular sites } \\
\text { of increased ROS production }\end{array}$ & $\begin{array}{l}\text { Lack of previous evidence of increased redox } \\
\text { dysfunction in patients analyzed } \\
\text { Some antioxidants may themselves become } \\
\text { prooxidants in the absence of a coordinated } \\
\text { antioxidant response } \\
\text { Unspecific scavenging of ROS may disrupt } \\
\text { physiological functions }\end{array}$ \\
$\begin{array}{l}\text { Some patients may be at an advanced stage of } \\
\text { disease exhibiting irreversible damage } \\
\text { Patients treated simultaneously with drugs that } \\
\text { interfere with oxidant status (aspirin, lipid } \\
\text { lowering agents, antihypertensive drugs) } \\
\text { Lack of validated oxidative stress biomarkers } \\
\text { for risk stratification and monitoring of therapy }\end{array}$ \\
\hline
\end{tabular}

Table 8. Possible reasons for the failure of clinical trials with antioxidants in cardiovascular diseases

\subsection{Antihypertensive treatments with direct and indirect antioxidant effects}

It is known that first-line antihypertensive drugs such as angiotensin II receptor blockers (ARB) and angiotensin converting enzyme inhibitors (ACEi) can reduce oxidative stress due to their inhibitory effect on angiotensin II, which is a major stimulus for the activation or upregulation of Nox enzymes $[5,296]$. ROS such as $\mathrm{O}_{2}-$ and $\mathrm{H}_{2} \mathrm{O}_{2}$ are widely recognized as important downstream mediators of Ang II physiological and pathological effects [303]. Nevertheless, some of these antihypertensive drugs also possess antioxidant effects independently of RAS inhibition. For example, captoptil, a thiol-containing ACEi, is a ROS scavenger and a metal chelator [304]. The ARBs candesartan and olmesartan also exhibit antioxidant effects independent of $\mathrm{AT}_{1}$ receptor blockade or blood pressure control [305307]. In addition, other agents belonging to the beta-blocker or calcium channel blocker drug classes have also been shown to exert antioxidant effects unrelated to their blood pressure lowering action. The beta-blockers carvedilol and nebivolol appear to possess ROS scavenging properties as well as inhibitory effects on ROS production, such as the inhibition of Nox activation [308, 309]. In addition, nebivolol also increases NO release from the endothelium, thus attenuating oxidative stress effects on endothelium-dependent vasodilation [309, 310]. The calcium channel blocker lacidipine has also been demonstrated 
to have a potent antioxidant activity and to reduce the intracellular production of ROS induced by oxidized LDL [311,312]. Therefore, even though convincing evidence is lacking regarding a clinical therapeutic effect of antioxidants, there is extensive data showing that currently approved antihypertensive treatments have the ability to modify oxidative stress status.

\section{Conclusions}

Extensive experimental evidence has shown that unbalanced ROS and/or RNS production can disturb several physiological functions, leading to the genesis and progression of arterial hypertension. Many studies have observed marked alterations in direct and indirect oxidative stress biomarkers, such as lipid peroxidation products, prooxidant enzymes and antioxidant defenses. However, most clinical trials with antioxidants have failed to demonstrate a protective effect on blood pressure and cardiovascular function. This does not necessarily exclude a role for oxidative stress in human cardiovascular diseases but instead suggests that other approaches should be addopted to recover redox homeostasis. The inhibition of Nox enzymes appears to be a promising strategy as these enzymes are major sources of ROS overproduction at cardiovascular and renal sites of blood pressure control. Indeed, several drugs already in use for the treatment of hypertension (e.g. ARBs, $\mathrm{ACEi}$, the $\beta$-blocker nebivolol) or dyslipidemia (statins) are known to reduce the activation of Nox enzymes. In addition, there is an urgent need to implement universally validated approaches to evaluate oxidative status in human patients. These should cover a broader range of redox biomarkers and would add valuable information for risk stratification and therapeutic monitoring in human patients.

\section{Acknowledgments}

"This work was supported by FEDER funds via COMPETE and by national funds through FCT - Portuguese Foundation for Science and Technology [project grant: PTDC/SAUTOX/114166/2009]."

\section{Author details}

Teresa Sousa, Joana Afonso and António Albino-Teixeira

Department of Pharmacology and Therapeutics, Faculty of Medicine, University of Porto, Portugal

Félix Carvalho

REQUIMTE, Laboratory of Toxicology, Department of Biological Sciences, Faculty of Pharmacy, University of Porto, Portugal 


\section{References}

[1] Droge, W. (2002) Free radicals in the physiological control of cell function. Physiol Rev 82: 47-95.

[2] Jones, D.P. (2008) Radical-free biology of oxidative stress. Am J Physiol Cell Physiol 295: C849-868.

[3] Turko, I.V., Murad, F. (2002) Protein nitration in cardiovascular diseases. Pharmacol Rev 54: 619-634.

[4] Valko, M., Leibfritz, D., Moncol, J., Cronin, M.T., Mazur, M., Telser, J. (2007) Free radicals and antioxidants in normal physiological functions and human disease. Int J Biochem Cell Biol 39: 44-84.

[5] Paravicini, T.M., Touyz, R.M. (2008) NADPH oxidases, reactive oxygen species, and hypertension: clinical implications and therapeutic possibilities. Diabetes Care 31 Suppl 2: S170-180.

[6] Pham-Huy, L., He, H., Pham-Huy, C. (2008) Free Radicals, Antioxidants in Disease and Health. Int J Biomed Sci 4: 89-96.

[7] Ardanaz, N., Pagano, P.J. (2006) Hydrogen peroxide as a paracrine vascular mediator: regulation and signaling leading to dysfunction. Exp Biol Med (Maywood) 231: 237251.

[8] Datla, S.R., Griendling, K.K. (2010) Reactive oxygen species, NADPH oxidases, and hypertension. Hypertension 56: 325-330.

[9] Griendling, K.K., FitzGerald, G.A. (2003) Oxidative stress and cardiovascular injury: Part I: basic mechanisms and in vivo monitoring of ROS. Circulation 108: 1912-1916.

[10] Bedard, K., Krause, K.-H. (2007) The NOX family of ROS-generating NADPH oxidases: Physiology and pathophysiology. Physiol Rev 87: 245-313.

[11] Geiszt, M., Leto, T.L. (2004) The Nox family of NAD(P)H oxidases: Host defense and beyond. J Biol Chem 279: 51715-51718.

[12] Nistala, R., Whaley-Connell, A., Sowers, J.R. (2008) Redox control of renal function and hypertension. Antiox Redox Signal 10: 2047-2089.

[13] Brandes, R.P., Takac, I., Schroeder, K. (2011) No Superoxide-No Stress? Nox4, the Good NADPH Oxidase! Arterioscler Thromb Vasc Biol 31: 1255-1257.

[14] Brown, D.I., Griendling, K.K. (2009) Nox proteins in signal transduction. Free Rad Biol Med 47: 1239-1253.

[15] Berry, C.E., Hare, J.M. (2004) Xanthine oxicloreductase and cardiovascular disease: molecular mechanisms and pathophysiological implications. J Physiol (London) 555: 589-606.

[16] Pacher, P., Nivorozhkin, A., Szabo, C. (2006) Therapeutic effects of xanthine oxidase inhibitors: renaissance half a century after the discovery of allopurinol. Pharmacol Rev 58: 87-114.

[17] Houston, M., Estevez, A., Chumley, P., Aslan, M., Marklund, S., Parks, D.A., Freeman,B.A. (1999) Binding of xanthine oxidase to vascular endothelium - Kinetic characterization and oxidative impairment of nitric oxide-dependent signaling. J Biol 
Chem 274: 4985-4994.

[18] Becker, B.F. (1993) Towards the physiological function of uric acid. Free Rad Biol Med 14: 615-631.

[19] Hink, H.U., Santanam, N., Dikalov, S., McCann, L., Nguyen, A.D., Parthasarathy, S., Harrison, D.G., Fukai, T. (2002) Peroxidase properties of extracellular superoxide dismutase - Role of uric acid in modulating in vivo activity. Arterioscler Thromb Vasc Biol 22: $1402-1408$.

[20] Hooper, D.C., Spitsin, S., Kean, R.B., Champion, J.M., Dickson, G.M., Chaudhry, I., Koprowski, H. (1998) Uric acid, a natural scavenger of peroxynitrite, in experimental allergic encephalomyelitis and multiple sclerosis. Proc Natl Acad Sci USA 95: 675-680.

[21] Kuzkaya, N., Weissmann, N., Harrison, D.G., Dikalov, S. (2005) Interactions of peroxynitrite with uric acid in the presence of ascorbate and thiols: implications for uncoupling endothelial nitric oxide synthase. Biochem Pharmacol 70: 343-354.

[22] Sevanian, A., Davies, K.J., Hochstein, P. (1985) Conservation of vitamin C by uric acid in blood. J Free Rad Biol Med 1: 117-124.

[23] Johnson, R.J., Kang, D.H., Feig, D., Kivlighn, S., Kanellis, J., Watanabe, S., Tuttle, K.R., Rodriguez-Iturbe, B., Herrera-Acosta, J., Mazzali, M. (2003) Is there a pathogenetic role for uric acid in hypertension and cardiovascular and renal disease? Hypertension 41: 1183-1190.

[24] Waring, W.S., Webb, D.J., Maxwell, S.R.J. (2000) Uric acid as a risk factor for cardiovascular disease. QJM 93: 707-713.

[25] Kirschbaum, B. (2001) Renal regulation of plasma total antioxidant capacity. Med Hypotheses 56: 625-629.

[26] Storey, K.B. (1996) Oxidative stress: Animal adaptations in nature. Braz J Med Biol Res 29: $1715-1733$.

[27] Addabbo, F., Montagnani, M., Goligorsky, M.S. (2009) Mitochondria and Reactive Oxygen Species. Hypertension 53: 885-892.

[28] Sugamura, K., Keaney, J.F., Jr. (2011) Reactive oxygen species in cardiovascular disease. Free Radic Biol Med 51: 978-992.

[29] Munzel, T., Gori, T., Bruno, R.M., Taddei, S. (2010) Is oxidative stress a therapeutic target in cardiovascular disease? Eur Heart J 31: 2741-2748.

[30] Chan, S.H., Wu, K.L., Chang, A.Y., Tai, M.H., Chan, J.Y. (2009) Oxidative impairment of mitochondrial electron transport chain complexes in rostral ventrolateral medulla contributes to neurogenic hypertension. Hypertension 53: 217-227.

[31] Dikalova, A.E., Bikineyeva, A.T., Budzyn, K., Nazarewicz, R.R., McCann, L., Lewis, W., Harrison, D.G., Dikalov, S.I. (2010) Therapeutic Targeting of Mitochondrial Superoxide in Hypertension. Circ Res 107: 106-U221.

[32] Elks, C.M., Mariappan, N., Haque, M., Guggilam, A., Majid, D.S., Francis, J. (2009) Chronic NF-\{kappa\}B blockade reduces cytosolic and mitochondrial oxidative stress and attenuates renal injury and hypertension in SHR. Am J Physiol Renal Physiol 296: F298-305.

[33] Briones, A.M., Touyz, R.M. (2010) Oxidative stress and hypertension: current concepts. 
Curr Hypertens Rep 12: 135-142.

[34] Li, H., Witte, K., August, M., Brausch, I., Godtel-Armbrust, U., Habermeier, A., Closs, E.I., Oelze, M., Munzel, T., Forstermann, U. (2006) Reversal of endothelial nitric oxide synthase uncoupling and up-regulation of endothelial nitric oxide synthase expression lowers blood pressure in hypertensive rats. J Am Coll Cardiol 47: 2536-2544.

[35] Vera, R., Sanchez, M., Galisteo, M., Concepcion Villar, I., Jimenez, R., Zarzuelo, A., PerezVizcaino, F., Duarte, J. (2007) Chronic administration of genistein improves endothelial dysfunction in spontaneously hypertensive rats: involvement of eNOS, caveolin and calmodulin expression and NADPH oxidase activity. Clin Sci 112: 183-191.

[36] Wassmann, S., Wassmann, K., Nickenig, G. (2004) Modulation of oxidant and antioxidant enzyme expression and function in vascular cells. Hypertension 44: 381-386.

[37] Malle, E., Buch, T., Grone, H.J. (2003) Myeloperoxidase in kidney disease. Kidney Int 64: 1956-1967.

[38] Green, P.S., Mendez, A.J., Jacob, J.S., Crowley, J.R., Growdon, W., Hyman, B.T., Heinecke, J.W. (2004) Neuronal expression of myeloperoxidase is increased in Alzheimer's disease. J Neurochem 90: 724-733.

[39] La Rocca, G., Di Stefano, A., Eleuteri, E., Anzalone, R., Magno, F., Corrao, S., Loria, T., Martorana, A., Di Gangi, C., Colombo, M., Sansone, F., Patane, F., Farina, F., Rinaldi, M., Cappello, F., Giannuzzi, P., Zummo, G. (2009) Oxidative stress induces myeloperoxidase expression in endocardial endothelial cells from patients with chronic heart failure. Basic Res Cardiol 104: 307-320.

[40] Xu, J., Xie, Z., Reece, R., Pimental, D., Zou, M.H. (2006) Uncoupling of endothelial nitric oxidase synthase by hypochlorous acid: role of $\mathrm{NAD}(\mathrm{P}) \mathrm{H}$ oxidase-derived superoxide and peroxynitrite. Arterioscler Thromb Vasc Biol 26: 2688-2695.

[41] Cai, H., Harrison, D.G. (2000) Endothelial dysfunction in cardiovascular diseases - The role of oxidant stress. Circ Res 87: 840-844.

[42] Didion, S.P., Ryan, M.J., Baumbach, G.L., Sigmund, C.D., Faraci, F.M. (2002) Superoxide contributes to vascular dysfunction in mice that express human renin and angiotensinogen. Am J Physiol Heart Circ Physiol 283: H1569-H1576.

[43] Lassegue, B., Griendling, K.K. (2004) Reactive oxygen species in hypertension; An update. Am J Hypertens 17: 852-860.

[44] Rathaus, M., Bernheim, J. (2002) Oxygen species in the microvascular environment: regulation of vascular tone and the development of hypertension. Nephrol Dial Transplant 17: 216-221.

[45] Touyz, R.M. (2003) Reactive oxygen species in vascular biology: role in arterial hypertension. Exp Rev Cardiov Ther 1: 91-106.

[46] Cowley, A.W., Jr. (2008) Renal Medullary Oxidative Stress, Pressure-Natriuresis, and Hypertension. Hypertension 52: 777-786.

[47] Tai, M.H., Wang, L.L., Wu, K.L.H., Chan, J.Y. (2005) Increased superoxide anion in rostral ventrolateral medulla contributes to hypertension in spontaneously hypertensive rats via interactions with nitric oxide. Free Rad Biol Med 38: 450-462.

[48] Makino, A., Skelton, M.M., Zou, A.P., Cowley, A.W., Jr. (2003) Increased renal medullary 
H2O2 leads to hypertension. Hypertension 42: 25-30.

[49] Sousa, T., Oliveira, S., Afonso, J., Morato, M., Patinha, D., Fraga, S., Carvalho, F., AlbinoTeixeira, A. (2012) Role of H(2) o(2) in Hypertension, Renin-Angiotensin System Activation and Renal Medullary Disfunction Caused by Angiotensin II. Br J Pharmacol: in press.

[50] Sousa, T., Pinho, D., Morato, M., Marques-Lopes, J., Fernandes, E., Afonso, J., Oliveira, S., Carvalho, F., Albino-Teixeira, A. (2008) Role of superoxide and hydrogen peroxide in hypertension induced by an antagonist of adenosine receptors. Eur J Pharmacol 588: 267-276.

[51] Cai, H. (2005) NAD(P)H oxidase-dependent self-propagation of hydrogen peroxide and vascular disease. Circ Res 96: 818-822.

[52] Asghar, M., Banday, A.A., Fardoun, R.Z., Lokhandwala, M.F. (2006) Hydrogen peroxide causes uncoupling of dopamine D1-like receptors from $G$ proteins via a mechanism involving protein kinase $C$ and G-protein-coupled receptor kinase 2. Free Rad Biol Med 40: $13-20$.

[53] Chen, Y.F., Cowley, A.W., Jr., Zou, A.P. (2003) Increased H(2)O(2) counteracts the vasodilator and natriuretic effects of superoxide dismutation by tempol in renal medulla. Am J Physiol Regul Integr Comp Physiol 285: R827-833.

[54] Gao, Y.J., Hirota, S., Zhang, D.W., Janssen, L.J., Lee, R. (2003) Mechanisms of hydrogenperoxide-induced biphasic response in rat mesenteric artery. Br J Pharmacol 138: 10851092.

[55] Gao, Y.J., Lee, R. (2001) Hydrogen peroxide induces a greater contraction in mesenteric arteries of spontaneously hypertensive rats through thromboxane $\mathrm{A}(2)$ production. $\mathrm{Br} \mathrm{J}$ Pharmacol 134: 1639-1646.

[56] Lin, H.H., Chen, C.H., Hsieh, W.K., Chiu, T.H., Lai, C.C. (2003) Hydrogen peroxide increases the activity of rat sympathetic preganglionic neurons in vivo and in vitro. Neuroscience 121: 641-647.

[57] Rodriguez-Martinez, M.A., Garcia-Cohen, E.C., Baena, A.B., Gonzalez, R., Salaices, M., Marin, J. (1998) Contractile responses elicited by hydrogen peroxide in aorta from normotensive and hypertensive rats. Endothelial modulation and mechanism involved. Br J Pharmacol 125: 1329-1335.

[58] Thakali, K., Davenport, L., Fink, G.D., Watts, S.W. (2006) Pleiotropic effects of hydrogen peroxide in arteries and veins from normotensive and hypertensive rats. Hypertension 47: 482-487.

[59] Didion, S., Chrissobolis, S., Faraci, F.M. (2008) Oxidative Stress in Hypertension. In: Miwa, Beckman, Muller, editors. Aging Medicine: Oxidative Stress in Aging 3: 229-251.

[60] Kristal, B., Shurtz-Swirski, R., Chezar, J., Manaster, J., Levy, R., Shapiro, G., Weissman, I., Shasha, S.M., Sela, S. (1998) Participation of peripheral polymorphonuclear leukocytes in the oxidative stress and inflammation in patients with essential hypertension. Am J Hypertens 11: 921-928.

[61] Lacy, F., Kailasam, M.T., O'Connor, D.T., Schmid-Schonbein, G.W., Parmer, R.J. (2000) Plasma hydrogen peroxide production in human essential hypertension - Role of heredity, gender, and ethnicity. Hypertension 36: 878-884.

[62] Lacy, F., O'Connor, D.T., Schmid-Schonbein, G.W. (1998) Plasma hydrogen peroxide 
production in hypertensives and normotensive subjects at genetic risk of hypertension. J Hypertens 16: 291-303.

[63] Dhawan, V., Jain, S. (2004) Effect of garlic supplementation on oxidized low density lipoproteins and lipid peroxidation in patients of essential hypertension. Mol Cell Biochem 266: 109-115.

[64] Kedziora-Kornatowska, K., Czuczejko, J., Pawluk, H., Kornatowski, T., Motyl, J., Szadujkis-Szadurski, L., Szewczyk-Golec, K., Kedziora, J. (2004) The markers of oxidative stress and activity of the antioxidant system in the blood of elderly patients with essential arterial hypertension. Cell Mol Biol Lett 9: 635-641.

[65] Redon, J., Oliva, M.R., Tormos, C., Giner, V., Chaves, J., Iradi, A., Saez, G.T. (2003) Antioxidant activities and oxidative stress byproducts in human hypertension. Hypertension 41: 1096-1101.

[66] Zhou, L., Xiang, W., Potts, J., Floyd, M., Sharan, C., Yang, H., Ross, J., Nyanda, A.M., Guo, Z. (2006) Reduction in extracellular superoxide dismutase activity in African- American patients with hypertension. Free Rad Biol Med 41: 1384-1391.

[67] Wen, Y., Killalea, S., McGettigan, P., Feely, J. (1996) Lipid peroxidation and antioxidant vitamins $C$ and $E$ in hypertensive patients. Ir J Med Sci 165: 210-212.

[68] Labios, M., Martinez, M., Gabriel, F., Guiral, V., Ruiz-Aja, S., Beltran, B., Munoz, A. (2008) Effects of eprosartan on mitochondrial membrane potential and $\mathrm{H}(2) \mathrm{O}(2)$ levels in leucocytes in hypertension. J Hum Hypertens 22: 493-500.

[69] Lyamina, N.P., Dolotovskaya, P.V., Lyamina, S.V., Malyshev, I.Y., Manukhina, E.B. (2003) Nitric oxide production and intensity of free radical processes in young men with high normal and hypertensive blood pressure. Med Sci Monit 9: CR304-310.

[70] Sierra, M., Gonzalez, A., Gomez-Alamillo, C., Monreal, I., Huarte, E., Gil, A., SanchezCasajus, A., Diez, J. (1998) Decreased excretion of nitrate and nitrite in essential hypertensives with renal vasoconstriction. Kidney Int 54: S10-S13.

[71] San Jose, G., Moreno, M.U., Olivan, S., Beloqui, O., Fortuno, A., Diez, J., Zalba, G. (2004) Functional effect of the p22(phox) -930(A/G) polymorphism on p22(phox) expression and NADPH oxidase activity in hypertension. Hypertension 44: 163-169.

[72] Russo, C., Olivieri, O., Girelli, D., Faccini, G., Zenari, M.L., Lombardi, S., Corrocher, R. (1998) Anti-oxidant status and lipid peroxidation in patients with essential hypertension. J Hypertens 16: 1267-1271.

[73] Kedziora-Kornatowska, K., Kornatowski, T., Bartosz, G., Pawluk, H., Czuczejko, J., Kedziora, J., Szadujkis-Szadurski, L. (2006) Production of nitric oxide, lipid peroxidation and oxidase activity of ceruloplasmin in blood of elderly patients with primary hypertension. Effects of perindopril treatment. Aging Clin Exp Res 18: 1-6.

[74] Rodrigo, R., Prat, H., Passalacqua, W., Araya, J., Guichard, C., Bachler, J.P. (2007) Relationship between oxidative stress and essential hypertension. Hypertension Res 30: 1159-1167.

[75] Minuz, P., Patrignani, P., Gaino, S., Degan, M., Menapace, L., Tommasoli, R., Seta, F., Capone, M.L., Tacconelli, S., Palatresi, S., Bencini, C., Del Vecchio, C., Mansueto, G., Arosio, E., Santonastaso, C.L., Lechi, A., Morganti, A., Patrono, C. (2002) Increased oxidative stress and platelet activation in patients with hypertension and renovascular disease. Circulation 106: 2800-2805. 
[76] Espinosa, O., Jimenez-Almazan, J., Chaves, F.J., Tormos, M.C., Clapes, S., Iradi, A., Salvador, A., Fandos, M., Redon, J., Saez, G.T. (2007) Urinary 8-oxo-7,8-dihydro-2 ' - deoxyguanosine (8-oxo-dG), a reliable oxidative stress marker in hypertension. Free Rad Res 41: 546-554.

[77] Rosello-Lleti, E., Garcia de Burgos, F., Morillas, P., Cortes, R., Martinez-Dolz, L., Almenar, L., Grigorian, L., Orosa, P., Portoles, M., Bertomeu, V., Rivera, M. (2011) Impact of Cardiovascular Risk Factors and Inflammatory Status on Urinary 8-OHdG in Essential Hypertension. Am J Hypertens 25: 236-242.

[78] Maggi, E., Marchesi, E., Ravetta, V., Falaschi, F., Finardi, G., Bellomo, G. (1993) Low- density lipoprotein oxidation in essential hypertension. J Hypertens 11: 1103-1111.

[79] Santangelo, L., Cigliano, L., Montefusco, A., Spagnuolo, M.S., Nigro, G., Golino, P., Abrescia, P. (2003) Evaluation of the antioxidant response in the plasma of healthy or hypertensive subjects after short-term exercise. J Hum Hypertens 17: 791-798.

[80] Alderman, M.H., Cohen, H., Madhavan, S., Kivlighn, S. (1999) Serum uric acid and cardiovascular events in successfully treated hypertensive patients. Hypertension 34: 144-150.

[81] Tse, W.Y., Maxwell, S.R.J., Thomason, H., Blann, A., Thorpe, G.H.G., Waite, M., Holder, R. (1994) Antioxidant status in controlled and uncontrolled hypertension and its relationship to endothelial damage. J Hum Hypertens 8: 843-849.

[82] Subash, P., Premagurumurthy, K., Sarasabharathi, A., Cherian, K.M. (2010) Total antioxidant status and oxidative DNA damage in a South Indian population of essential hypertensives. J Hum Hypertens 24: 475-482.

[83] Kashyap, M.K., Yadav, V., Sherawat, B.S., Jain, S., Kumari, S., Khullar, M., Sharma, P.C., Nath, R. (2005) Different antioxidants status, total antioxidant power and free radicals in essential hypertension. Mol Cell Biochem 277: 89-99.

[84] Vaziri, N.D., Wang, X.Q., Oveisi, F., Rad, B. (2000) Induction of oxidative stress by glutathione depletion causes severe hypertension in normal rats. Hypertension 36: 142- 146.

[85] Baumer, A.T., Kruger, C.A., Falkenberg, J., Freyhaus, H.T., Rosen, R., Fink, K., Rosenkranz, S. (2007) The NAD(P)H oxidase inhibitor apocynin improves endothelial NO/superoxide balance and lowers effectively blood pressure in spontaneously hypertensive rats: comparison to calcium channel blockade. Clin Exp Hypertens 29: 287-299.

[86] Beswick, R.A., Dorrance, A.M., Leite, R., Webb, R.C. (2001) NADH/NADPH oxidase and enhanced superoxide production in the mineralocorticoid hypertensive rat. Hypertension 38: 1107-1111.

[87] Zhang, Y., Croft, K.D., Mori, T.A., Schyvens, C.G., McKenzie, K.U., Whitworth, J.A. (2004) The antioxidant tempol prevents and partially reverses dexamethasone-induced hypertension in the rat. Am J Hypertens 17: 260-265.

[88] Dikalova, A., Clempus, R., Lassegue, B., Cheng, G.J., McCoy, J., Dikalov, S., Martin, A.S., Lyle, A., Weber, D.S., Weiss, D., Taylor, R., Schmidt, H., Owens, G.K., Lambeth, J.D., Griendling, K.K. (2005) Nox1 overexpression potentiates angiotensin II-induced hypertension and vascular smooth muscle hypertrophy in transgenic mice. Circulation 112: 2668-2676.

[89] Godin, N., Liu, F., Lau, G.J., Brezniceanu, M.-L., Chenier, I., Filep, J.G., Ingelfinger, J.R., Zhang, S.-L., Chan, J.S.D. (2010) Catalase overexpression prevents hypertension and tubular apoptosis in angiotensinogen transgenic mice. Kidney Int 77: 1086-1097. 
[90] Wilcox, C.S. (2005) Oxidative stress and nitric oxide deficiency in the kidney: a critical link to hypertension? Am J Physiol-Regul Integr Comp Physiol 289: R913-R935.

[91] Paravicini, T.M., Touyz, R.M. (2006) Redox signaling in hypertension. Cardiov Res 71: 247-258.

[92] Grossman, E. (2008) Does increased oxidative stress cause hypertension? Diabetes Care 31 Suppl 2: S185-189.

[93] Baykal, Y., Yilmaz, M.I., Celik, T., Gok, F., Rehber, H., Akay, C., Kocar, I.H. (2003) Effects of antihypertensive agents, alpha receptor blockers, beta blockers, angiotensin- converting enzyme inhibitors, angiotensin receptor blockers and calcium channel blockers, on oxidative stress. J Hypertens 21: 1207-1211.

[94] de Cavanagh, E.M., Ferder, L.F., Ferder, M.D., Stella, I.Y., Toblli, J.E., Inserra, F. (2010) Vascular structure and oxidative stress in salt-loaded spontaneously hypertensive rats: effects of losartan and atenolol. Am J Hypertens 23: 1318-1325.

[95] Sugiura, T., Kondo, T., Kureishi-Bando, Y., Numaguchi, Y., Yoshida, O., Dohi, Y., Kimura, G., Ueda, R., Rabelink, T.J., Murohara, T. (2008) Nifedipine improves endothelial function role of endothelial progenitor cells. Hypertension 52: 491-498.

[96] Wingler, K., Hermans, J.J., Schiffers, P., Moens, A., Paul, M., Schmidt, H.H. (2011) NOX1, 2, 4, 5: counting out oxidative stress. Br J Pharmacol 164: 866-883.

[97] Dalle-Donne, I., Rossi, R., Colombo, R., Giustarini, D., Milzani, A. (2006) Biomarkers of oxidative damage in human disease. Clin Chem 52: 601-623.

[98] de Zwart, L.L., Meerman, J.H., Commandeur, J.N., Vermeulen, N.P. (1999) Biomarkers of free radical damage applications in experimental animals and in humans. Free Radic Biol Med 26: 202-226.

[99] Atkinson, A. (2001) Biomarkers and surrogate endpoints: preferred definitions and conceptual framework. Clin Pharmacol Ther 69: 89-95.

[100] Offord, E., van Poppel, G., Tyrrell, R. (2000) Markers of oxidative damage and antioxidant protection: current status and relevance to disease. Free Radic Res 33 Suppl: S5-19.

[101] Hancock, J.T., Desikan, R., Neill, S.J. (2001) Role of reactive oxygen species in cell signalling pathways. Biochem Soc Trans 29: 345-350.

[102] Sohal, R.S., Dubey, A. (1994) Mitochondrial oxidative damage, hydrogen peroxide release, and aging. Free Radic Biol Med 16: 621-626.

[103] Taniyama, Y., Griendling, K.K. (2003) Reactive oxygen species in the vasculature: molecular and cellular mechanisms. Hypertension 42: 1075-1081.

[104] Halliwell, B., Gutteridge, J.M. (1989) Free Rad Biol Med, 2nd edition, Clarendon Press, Oxford, UK.

[105] Sies, H. (1993) Strategies of antioxidant defense. Eur J Biochem 215: 213-219.

[106] Frei, B., Stocker, R., Ames, B.N. (1988) Antioxidant defenses and lipid peroxidation in human blood plasma. Proc Natl Acad Sci U S A 85: 9748-9752.

[107] Shull, S., Heintz, N.H., Periasamy, M., Manohar, M., Janssen, Y.M., Marsh, J.P., Mossman, B.T. (1991) Differential regulation of antioxidant enzymes in response to oxidants. J Biol Chem 266: 24398-24403. 
[108] Young, I.S., Woodside, J.V. (2001) Antioxidants in health and disease. J Clin Pathol 54: 176-186.

[109] Hayes, J.D., Pulford, D.J. (1995) The glutathione S-transferase supergene family: regulation of GST and the contribution of the isoenzymes to cancer chemoprotection and drug resistance. Crit Rev Biochem Mol Biol 30: 445-600.

[110] Kalinina, E.V., Chernov, N.N., Saprin, A.N. (2008) Involvement of thio-, peroxi-, and glutaredoxins in cellular redox-dependent processes. Biochemistry (Mosc) 73: 1493- 1510.

[111] Farmand, F., Ehdaie, A., Roberts, C.K., Sindhu, R.K. (2005) Lead-induced dysregulation of superoxide dismutases, catalase, glutathione peroxidase, and guanylate cyclase. Environ Res 98: 33-39.

[112] Sainz, J., Wangensteen, R., Rodriguez Gomez, I., Moreno, J.M., Chamorro, V., Osuna, A., Bueno, P., Vargas, F. (2005) Antioxidant enzymes and effects of tempol on the development of hypertension induced by nitric oxide inhibition. Am J Hypertens 18: 871-877.

[113] Gille, G., Sigler, K. (1995) Oxidative stress and living cells. Folia Microbiol (Praha) 40: 131-152.

[114] Chan, P., Liao, S.S., Hsu, C.T., Lee, Y.S., Tomlinson, B., Kuo, J.S., Cheng, J.T. (1999) Superoxide dismutase gene expression and activity in the brain of spontaneously hypertensive rats and normotensive rats. Chin Med J (Engl) 112: 1119-1124.

[115] Nozoe, M., Hirooka, Y., Koga, Y., Sagara, Y., Kishi, T., Engelhardt, J.F., Sunagawa, K. (2007) Inhibition of Rac1-derived reactive oxygen species in nucleus tractus solitarius decreases blood pressure and heart rate in stroke-prone spontaneously hypertensive rats. Hypertension 50: 62-68.

[116] Chan, S.H., Tai, M.H., Li, C.Y., Chan, J.Y. (2006) Reduction in molecular synthesis or enzyme activity of superoxide dismutases and catalase contributes to oxidative stress and neurogenic hypertension in spontaneously hypertensive rats. Free Radic Biol Med 40: 2028-2039.

[117] Adler, S., Huang, H., Loke, K.E., Xu, X., Tada, H., Laumas, A., Hintze, T.H. (2001) Endothelial nitric oxide synthase plays an essential role in regulation of renal oxygen consumption by NO. Am J Physiol Renal Physiol 280: F838-843.

[118] Simao, S., Gomes, P., Pinto, V., Silva, E., Amaral, J.S., Igreja, B., Afonso, J., Serrao, M.P., Pinho, M.J., Soares-da-Silva, P. (2011) Age-related changes in renal expression of oxidant and antioxidant enzymes and oxidative stress markers in male SHR and WKY rats. Exp Gerontol 46: 468-474.

[119] Potenza, M.A., Addabbo, F., Montagnani, M. (2009) Vascular actions of insulin with implications for endothelial dysfunction. Am J Physiol Endocrinol Metab 297: E568-577. Zheng, H., Yu, Y.S. (2012) Chronic hydrogen-rich saline treatment attenuates vascular

[120] dysfunction in spontaneous hypertensive rats. Biochem Pharmacol 83: 1269-1277.

[121] Ulker, S., McMaster, D., McKeown, P.P., Bayraktutan, U. (2003) Impaired activities of antioxidant enzymes elicit endothelial dysfunction in spontaneous hypertensive rats despite enhanced vascular nitric oxide generation. Cardiovasc Res 59: 488-500.

[122] Polizio, A.H., Pena, C. (2005) Effects of angiotensin II type 1 receptor blockade on the oxidative stress in spontaneously hypertensive rat tissues. Regul Pept 128: 1-5. 
[123] Xu, Y., Gao, Q., Gan, X.B., Chen, L., Zhang, L., Zhu, G.Q., Gao, X.Y. (2011) Endogenous hydrogen peroxide in paraventricular nucleus mediates sympathetic activation and enhanced cardiac sympathetic afferent reflex in renovascular hypertensive rats. Exp Physiol 96: $1282-1292$.

[124] Fortepiani, L.A., Reckelhoff, J.F. (2005) Increasing oxidative stress with molsidomine increases blood pressure in genetically hypertensive rats but not normotensive controls. Am J Physiol Regul Integr Comp Physiol 289: R763-770.

[125] Kumar, U., Chen, J., Sapoznikhov, V., Canteros, G., White, B.H., Sidhu, A. (2005) Overexpression of inducible nitric oxide synthase in the kidney of the spontaneously hypertensive rat. Clin Exp Hypertens 27: 17-31.

[126] Zhang, L., Fujii, S., Kosaka, H. (2007) Effect of oestrogen on reactive oxygen species production in the aortas of ovariectomized Dahl salt-sensitive rats. J Hypertens 25: 407- 414.

[127] Kosower, N.S., Kosower, E.M. (1978) The glutathione status of cells. Int Rev Cytol 54: 109-160.

[128] Franco, R., DeHaven, W.I., Sifre, M.I., Bortner, C.D., Cidlowski, J.A. (2008) Glutathione depletion and disruption of intracellular ionic homeostasis regulate lymphoid cell apoptosis. J Biol Chem 283: 36071-36087.

[129] Schulz, J.B., Lindenau, J., Seyfried, J., Dichgans, J. (2000) Glutathione, oxidative stress and neurodegeneration. Eur J Biochem 267: 4904-4911.

[130] Singh, U., Devaraj, S., Jialal, I. (2005) Vitamin E, oxidative stress, and inflammation. Annu Rev Nutr 25: 151-174.

[131] Smith, A.R., Visioli, F., Hagen, T.M. (2002) Vitamin C matters: increased oxidative stress in cultured human aortic endothelial cells without supplemental ascorbic acid. FASEB J 16: 1102-1104.

[132] Waring, W.S. (2002) Uric acid: an important antioxidant in acute ischaemic stroke. QJM 95: 691-693.

[133] Stocker, R., Yamamoto, Y., McDonagh, A.F., Glazer, A.N., Ames, B.N. (1987) Bilirubin is an antioxidant of possible physiological importance. Science 235: 1043-1046.

[134] Lin, J.P., Vitek, L., Schwertner, H.A. (2010) Serum bilirubin and genes controlling bilirubin concentrations as biomarkers for cardiovascular disease. Clin Chem 56: 1535- 1543.

[135] Hu, M.L., Louie, S., Cross, C.E., Motchnik, P., Halliwell, B. (1993) Antioxidant protection against hypochlorous acid in human plasma. J Lab Clin Med 121: 257-262.

[136] Benzie, I.F., Strain, J.J. (1996) The ferric reducing ability of plasma (FRAP) as a measure of "antioxidant power": the FRAP assay. Anal Biochem 239: 70-76.

[137] Wayner, D.D., Burton, G.W., Ingold, K.U., Locke, S. (1985) Quantitative measurement of the total, peroxyl radical-trapping antioxidant capability of human blood plasma by controlled peroxidation. The important contribution made by plasma proteins. FEBS Lett 187: 33-37.

[138] Yanes, L., Romero, D., Iliescu, R., Cucchiarelli, V.E., Fortepiani, L.A., Santacruz, F., Bell, W., Zhang, H., Reckelhoff, J.F. (2005) Systemic arterial pressure response to two weeks of Tempol therapy in SHR: involvement of NO, the RAS, and oxidative stress. Am J Physiol Regul Integr Comp Physiol 288: R903-908. 
[139] Ghiselli, A., Serafini, M., Natella, F., Scaccini, C. (2000) Total antioxidant capacity as a tool to assess redox status: critical view and experimental data. Free Radic Biol Med 29: 1106-1114.

[140] Kanbay, M., Solak, Y., Dogan, E., Lanaspa, M.A., Covic, A. (2010) Uric acid in hypertension and renal disease: the chicken or the egg? Blood Purif 30: 288-295.

[141] Young, I.S. (2001) Measurement of total antioxidant capacity. J Clin Pathol 54: 339.

[142] Duffy, S.J., Gokce, N., Holbrook, M., Huang, A., Frei, B., Keaney, J.F., Jr., Vita, J.A. (1999) Treatment of hypertension with ascorbic acid. Lancet 354: 2048-2049.

[143] Newaz, M.A., Nawal, N.N., Rohaizan, C.H., Muslim, N., Gapor, A. (1999) alpha- Tocopherol increased nitric oxide synthase activity in blood vessels of spontaneously hypertensive rats. Am J Hypertens 12: 839-844.

[144] Ward, N.C., Hodgson, J.M., Puddey, I.B., Mori, T.A., Beilin, L.J., Croft, K.D. (2004) Oxidative stress in human hypertension: association with antihypertensive treatment, gender, nutrition, and lifestyle. Free Radic Biol Med 36: 226-232.

[145] Gutteridge, J.M., Halliwell, B. (1990) The measurement and mechanism of lipid peroxidation in biological systems. Trends Biochem Sci 15: 129-135.

[146] Halliwell, B., Whiteman, M. (2004) Measuring reactive species and oxidative damage in vivo and in cell culture: how should you do it and what do the results mean? Br J Pharmacol, 142: 231-55.

[147] Vincent, H.K., Taylor, A.G. (2006) Biomarkers and potential mechanisms of obesity- induced oxidant stress in humans. Int J Obes (Lond) 30: 400-418.

[148] Janicka, M., Kot-Wasik, A., Kot, J., Namiesnik, J. (2010) Isoprostanes-biomarkers of lipid peroxidation: their utility in evaluating oxidative stress and analysis. Int J Mol Sci 11: 46314659 .

[149] Soffler, C., Campbell, V.L., Hassel, D.M.(2010) Measurement of urinary F2- isoprostanes as markers of in vivo lipid peroxidation: a comparison of enzyme immunoassays with gas chromatography-mass spectrometry in domestic animal species. J Vet Diagn Invest. 22: 200-9.

[150] Greco, A., Minghetti, L., Levi, G. (2000) Isoprostanes, novel markers of oxidative injury, help understanding the pathogenesis of neurodegenerative diseases. Neurochem Res 25: 1357-1364.

[151] Kadiiska, M.B., Gladen, B.C., Baird, D.D., Germolec, D., Graham, L.B., Parker, C.E.,Nyska, A., Wachsman, J.T., Ames, B.N., Basu, S., Brot, N., Fitzgerald, G.A., Floyd, R.A.,George, M., Heinecke, J.W., Hatch, G.E., Hensley, K., Lawson, J.A., Marnett, L.J., Morrow, J.D., Murray, D.M., Plastaras, J., Roberts, L.J. 2nd, Rokach, J., Shigenaga, M.K., Sohal, R.S., Sun, J., Tice, R.R., Van Thiel, D.H., Wellner, D., Walter, P.B., Tomer, K.B., Mason, R.P., Barrett, J.C.(2005) Biomarkers of oxidative stress study II: are oxidation products of lipids, proteins, and DNA markers of CCl4 poisoning? Free Radic Biol Med 38:698-710.

[152] Milne GL, Yin H, Brooks JD, et al.: 2007, Quantification of F2-isoprostanes in biological fluids and tissues as a measure of oxidant stress. Methods Enzymol 433:113-126.

[153] Todorova, I., Simeonova, G. Kyuchukova, D., Dinev, D., Gadjeva, V. (2005) Reference values of oxidative stress parameters (MDA, SOD, CAT) in dogs and cats. Comp Clin Path 13: 190-194. 
[154] Huszar, G, Vigue, L. (1994) Correlation between the rate of lipid peroxidation and cellular maturity as measured by creatine kinase activity in human spermatozoa. J Androl 15: $71-7$.

[155] Janero, D.R. (1990) Malondialdehyde and thiobarbituric acid-reactivity as diagnostic indices of lipid peroxidation and peroxidative tissue injury. Free Radic Biol Med 9: 515- 540.

[156] Yeo, H.C., Helbock, H.J., Chyu, D.W., Ames, B.N. (1994) Assay of malondialdehyde in biological fluids by gas chromatography-mass spectrometry. Anal Biochem 220: 391- 396.

[157] Khaira, A., Mahajan, S., Kumar, A., Saraya, A., Tiwari, S.C., Prakash, S., Gupta, A., Bhowmik, D., Agarwal, S.K. (2011) Endothelial function and oxidative stress in chronic kidney disease of varying severity and the effect of acute hemodialysis. Ren Fail 33: 411- 417.

[158] Rumley, A.G., Woodward, M., Rumley, A., Rumley, J., Lowe, G.D. (2004) Plasma lipid peroxides: relationships to cardiovascular risk factors and prevalent cardiovascular disease. QJM 97: 809-816.

[159] Satoh, K. (1978) Serum lipid peroxide in cerebrovascular disorders determined by a new colorimetric method. Clin Chim Acta 90: 37-43.

[160] Yoneyama, Y., Sawa, R., Suzuki, S., Doi, D., Yoneyama, K., Otsubo, Y., Araki, T. (2002) Relationship between plasma malondialdehyde levels and adenosine deaminase activities in preeclampsia. Clin Chim Acta 322: 169-173.

[161] Tateishi, T., Yoshimine, N, Kuzuya, F. (1987) Serum lipid peroxide assayed by a new colorimetric method. Exp Gerontol 22 (2): 103-111.

[162] Uchida, K. (2003) 4-Hydroxy-2-nonenal: a product and mediator of oxidative stress.Prog Lipid Res 42: 318-343.

[163] Suzuki, H., Nakazato, K., Asayama, K., Masawa, N., Takamata, M., Sakata, N. (2002) The role of oxidative stress on pathogenesis of hypertensive arterial lesions in rat mesenteric arteries. Acta Histochem Cytochem 35: 287-293.

[164] Blasig, I.E., Grune, T., Schonheit, K., Rohde, E., Jakstadt, M., Haseloff, R.F., Siems,W.G. (1995) 4-Hydroxynonenal, a novel indicator of lipid peroxidation for reperfusion injury of the myocardium. Am J Physiol 269: H14-22.

[165] Esterbauer, H., Schaur, R., Zollner, H. (1991) Chemistry and biochemistry of 4- hydroxynonenal, malonaldehyde and related aldehydes. Free Rad Biol Med 11: 81-128.

[166] Michel, F., Bonnefont-Rousselot, D., Mas, E., Drai, J., Therond, P. (2008) [Biomarkers of lipid peroxidation: analytical aspects]. Ann Biol Clin (Paris) 66: 605-620.

[167] Abuja, P.M., Albertini, R. (2001) Methods for monitoring oxidative stress, lipid peroxidation and oxidation resistance of lipoproteins. Clin Chim Acta 306: 1-17.

[168] Kato, Y., Yoshida, A., Naito, M., Kawai, Y., Tsuji, K., Kitamura, M., Kitamoto, N., Osawa, T. (2004) Identification and quantification of N(epsilon)-(Hexanoyl)lysine in human urine by liquid chromatography/tandem mass spectrometry. Free Radic Biol Med 37: 1864-1874.

[169] Kato, Y., Miyake, Y., Yamamoto, K., Shimomura, Y., Ochi, H., Mori, Y., Osawa, T. (2000) Preparation of a monoclonal antibody to N(epsilon)-(Hexanonyl)lysine: application to the evaluation of protective effects of flavonoid supplementation against exercise-induced oxidative stress in rat skeletal muscle. Biochem Biophys Res Commun 274: 389-393. 
[170] Duarte, J., Perez-Palencia, R., Vargas, F., Ocete, M.A., Perez-Vizcaino, F., Zarzuelo, A., Tamargo, J. (2001) Antihypertensive effects of the flavonoid quercetin in spontaneously hypertensive rats. Br J Pharmacol 133: 117-124.

[171] Elmarakby, A.A., Imig, J.D. (2010) Obesity is the major contributor to vascular dysfunction and inflammation in high-fat diet hypertensive rats. Clin Sci (Lond) 118: 291-301.

[172] Galisteo, M., Garcia-Saura, M.F., Jimenez, R., Villar, I.C., Zarzuelo, A., Vargas, F., Duarte, J. (2004) Effects of chronic quercetin treatment on antioxidant defence system and oxidative status of deoxycorticosterone acetate-salt-hypertensive rats. Mol Cell Biochem 259: 91-99.

[173] De Miguel, C., Guo, C., Lund, H., Feng, D., Mattson, D.L. (2010) Infiltrating T lymphocytes in the kidney increase oxidative stress and participate in the development of hypertension and renal disease. Am J Physiol Renal Physiol 300: F734-742.

[174] Zhang, G.X., Kimura, S., Nishiyama, A., Shokoji, T., Rahman, M., Abe, Y. (2004) ROS during the acute phase of Ang II hypertension participates in cardiovascular MAPK activation but not vasoconstriction. Hypertension 43: 117-124.

[175] Meng, S., Roberts, L.J., 2nd, Cason, G.W., Curry, T.S., Manning, R.D., Jr. (2002) Superoxide dismutase and oxidative stress in Dahl salt-sensitive and -resistant rats. Am J Physiol Regul Integr Comp Physiol 283: R732-738.

[176] Paliege, A., Pasumarthy, A., Mizel, D., Yang, T., Schnermann, J., Bachmann, S. (2006) Effect of apocynin treatment on renal expression of COX-2, NOS1, and renin in WistarKyoto and spontaneously hypertensive rats. Am J Physiol Regul Integr Comp Physiol 290: R694-700.

[177] Takai, S., Jin, D., Ikeda, H., Sakonjo, H., Miyazaki, M. (2009) Significance of angiotensin II receptor blockers with high affinity to angiotensin II type 1 receptors for vascular protection in rats. Hypertens Res 32: 853-860.

[178] Asselin, C., Bouchard, B., Tardif, J.C., Des Rosiers, C. (2006) Circulating 4- hydroxynonenal-protein thioether adducts assessed by gas chromatography-mass spectrometry are increased with disease progression and aging in spontaneously hypertensive rats. Free Radic Biol Med 41: 97-105.

[179] de Cavanagh, E.M., Toblli, J.E., Ferder, L., Piotrkowski, B., Stella, I., Inserra, F. (2006) Renal mitochondrial dysfunction in spontaneously hypertensive rats is attenuated by losartan but not by amlodipine. Am J Physiol Regul Integr Comp Physiol 290: R1616- 1625.

[180] Zhang, A., Jia, Z., Wang, N., Tidwell, T.J., Yang, T. (2011) Relative contributions of mitochondria and NADPH oxidase to deoxycorticosterone acetate-salt hypertension in mice. Kidney Int 80: 51-60.

[181] Yamamoto, E., Tamamaki, N., Nakamura, T., Kataoka, K., Tokutomi, Y., Dong, Y.F., Fukuda, M., Matsuba, S., Ogawa, H., Kim-Mitsuyama, S. (2008) Excess salt causes cerebral neuronal apoptosis and inflammation in stroke-prone hypertensive rats through angiotensin II-induced NADPH oxidase activation. Stroke 39: 3049-3056.

[182] Cifuentes, M.E., Rey, F.E., Carretero, O.A., Pagano, P.J. (2000) Upregulation of p67(phox) and gp91(phox) in aortas from angiotensin II-infused mice. Am J Physiol Heart Circ Physiol 279: H2234-2240.

[183] Akasaki, T., Ohya, Y., Kuroda, J., Eto, K., Abe, I., Sumimoto, H., Iida, M. (2006) Increased expression of gp91phox homologues of $\mathrm{NAD}(\mathrm{P}) \mathrm{H}$ oxidase in the aortic media during 
chronic hypertension: involvement of the renin-angiotensin system. Hypertens Res 29: 813-820.

[184] Fukui, T., Ishizaka, N., Rajagopalan, S., Laursen, J.B., Capers, Q.t., Taylor, W.R., Harrison, D.G., de Leon, H., Wilcox, J.N., Griendling, K.K. (1997) p22phox mRNA expression and NADPH oxidase activity are increased in aortas from hypertensive rats. Circ Res 80: 45-51.

[185] Rajagopalan, S., Kurz, S., Munzel, T., Tarpey, M., Freeman, B.A., Griendling, K.K., Harrison, D.G. (1996) Angiotensin II-mediated hypertension in the rat increases vascular superoxide production via membrane NADH/NADPH oxidase activation. Contribution to alterations of vasomotor tone. J Clin Invest 97: 1916-1923.

[186] Virdis, A., Neves, M.F., Amiri, F., Touyz, R.M., Schiffrin, E.L. (2004) Role of NAD(P)H oxidase on vascular alterations in angiotensin II-infused mice. J Hypertens 22: 535-542.

[187] Suzuki, H., DeLano, F.A., Parks, D.A., Jamshidi, N., Granger, D.N., Ishii, H., Suematsu, M., Zweifach, B.W., Schmid-Schonbein, G.W. (1998) Xanthine oxidase activity associated with arterial blood pressure in spontaneously hypertensive rats. Proc Natl Acad Sci U S A 95: 4754-4759.

[188] DeLano, F.A., Parks, D.A., Ruedi, J.M., Babior, B.M., Schmid-Schonbein, G.W. (2006) Microvascular display of xanthine oxidase and NADPH oxidase in the spontaneously hypertensive rat. Microcirculation 13: 551-566.

[189] Breckwoldt, M.O., Chen, J.W., Stangenberg, L., Aikawa, E., Rodriguez, E., Qiu, S., Moskowitz, M.A., Weissleder, R. (2008) Tracking the inflammatory response in stroke in vivo by sensing the enzyme myeloperoxidase. Proc Natl Acad Sci U S A 105: 18584- 18589.

[190] Ersahin, M., Sehirli, O., Toklu, H.Z., Suleymanoglu, S., Emekli-Alturfan, E., Yarat, A., Tatlidede, E., Yegen, B.C., Sener, G. (2009) Melatonin improves cardiovascular function and ameliorates renal, cardiac and cerebral damage in rats with renovascular hypertension. J Pineal Res 47: 97-106.

[191] Wang, X., Desai, K., Clausen, J.T., Wu, L. (2004) Increased methylglyoxal and advanced glycation end products in kidney from spontaneously hypertensive rats. Kidney Int 66: 2315-2321.

[192] Bayorh, M.A., Ganafa, A.A., Emmett, N., Socci, R.R., Eatman, D., Fridie, I.L. (2005) Alterations in aldosterone and angiotensin II levels in salt-induced hypertension. Clin Exp Hypertens 27: 355-367.

[193] Zhan, C.D., Sindhu, R.K., Vaziri, N.D. (2004) Up-regulation of kidney NAD(P)H oxidase and calcineurin in SHR: reversal by lifelong antioxidant supplementation. Kidney Int 65: 219-227.

[194] Tanito, M., Nakamura, H., Kwon, Y.W., Teratani, A., Masutani, H., Shioji, K., Kishimoto, C., Ohira, A., Horie, R., Yodoi, J. (2004) Enhanced oxidative stress and impaired thioredoxin expression in spontaneously hypertensive rats. Antioxid Redox Signal 6: 89-97.

[195] Tyther, R., Ahmeda, A., Johns, E., Sheehan, D. (2009) Protein carbonylation in the kidney medulla of the spontaneously hypertensive rat. Proteomics Clin Appl 3: 338-346.

[196] Rodriguez-Iturbe, B., Ferrebuz, A., Vanegas, V., Quiroz, Y., Mezzano, S., Vaziri, N.D. (2005) Early and sustained inhibition of nuclear factor-kappaB prevents hypertension in spontaneously hypertensive rats. J Pharmacol Exp Ther 315: 51-57. 
[197] Diep, Q.N., El Mabrouk, M., Cohn, J.S., Endemann, D., Amiri, F., Virdis, A., Neves, M.F., Schiffrin, E.L. (2002) Structure, endothelial function, cell growth, and inflammation in blood vessels of angiotensin II-infused rats: role of peroxisome proliferator-activated receptor-gamma. Circulation 105: 2296-2302.

[198] Bayorh, M.A., Ganafa, A.A., Eatman, D., Walton, M., Feuerstein, G.Z. (2005) Simvastatin and losartan enhance nitric oxide and reduce oxidative stress in salt- induced hypertension. Am J Hypertens 18: 1496-1502.

[199] Hong, H.J., Hsiao, G., Cheng, T.H., Yen, M.H. (2001) Supplemention with tetrahydrobiopterin suppresses the development of hypertension in spontaneously hypertensive rats. Hypertension 38: 1044-1048.

[200] Elmarakby, A.A., Loomis, E.D., Pollock, J.S., Pollock, D.M. (2005) NADPH oxidase inhibition attenuates oxidative stress but not hypertension produced by chronic ET-1. Hypertension 45: 283-287.

[201] Schnackenberg, C.G., Wilcox, C.S. (1999) Two-week administration of tempol attenuates both hypertension and renal excretion of 8-Iso prostaglandin f2alpha. Hypertension 33: 424-428.

[202] Krug, S., Zhang, Y., Mori, T.A., Croft, K.D., Vickers, J.J., Langton, L.K., Whitworth, J.A. (2008) N-Acetylcysteine prevents but does not reverse dexamethasone-induced hypertension. Clin Exp Pharmacol Physiol 35: 979-981.

[203] Stefanska, J., Pawliczak, R. (2008) Apocynin: molecular aptitudes. Mediators Inflamm 2008: 106507.

[204] Selemidis, S., Sobey, C.G., Wingler, K., Schmidt, H.H., Drummond, G.R. (2008) NADPH oxidases in the vasculature: molecular features, roles in disease and pharmacological inhibition. Pharmacol Ther 120: 254-291.

[205] Heumuller, S., Wind, S., Barbosa-Sicard, E., Schmidt, H.H., Busse, R., Schroder, K., Brandes, R.P. (2008) Apocynin is not an inhibitor of vascular NADPH oxidases but an antioxidant. Hypertension 51: 211-217.

[206] Touyz, R.M. (2008) Apocynin, NADPH oxidase, and vascular cells: a complex matter. Hypertension 51: 172-174.

[207] Ximenes, V.F., Kanegae, M.P., Rissato, S.R., Galhiane, M.S. (2007) The oxidation of apocynin catalyzed by myeloperoxidase: proposal for NADPH oxidase inhibition. Arch Biochem Biophys 457: 134-141.

[208] Brandes, R.P. (2003) A radical adventure: the quest for specific functions and inhibitors of vascular NAPDH oxidases. Circ Res 92: 583-585.

[209] Rey, F.E., Cifuentes, M.E., Kiarash, A., Quinn, M.T., Pagano, P.J. (2001) Novel competitive inhibitor of $\mathrm{NAD}(\mathrm{P}) \mathrm{H}$ oxidase assembly attenuates vascular $\mathrm{O}(2)(-)$ and systolic blood pressure in mice. Circ Res 89: 408-414.

[210] George, J., Struthers, A.D. (2009) Role of urate, xanthine oxidase and the effects of allopurinol in vascular oxidative stress. Vasc Health Risk Manag 5: 265-272.

[211] Kelkar, A., Kuo, A., Frishman, W.H. (2011) Allopurinol as a cardiovascular drug. Cardiol Rev 19: 265-271.

[212] Moorhouse, P.C., Grootveld, M., Halliwell, B., Quinlan, J.G., Gutteridge, J.M. (1987) Al- 
lopurinol and oxypurinol are hydroxyl radical scavengers. FEBS Lett 213: 23-28.

[213] Schnackenberg, C.G., Welch, W.J., Wilcox, C.S. (1998) Normalization of blood pressure and renal vascular resistance in SHR with a membrane-permeable superoxide dismutase mimetic: role of nitric oxide. Hypertension 32: 59-64.

[214] Wilcox, C.S., Pearlman, A. (2008) Chemistry and antihypertensive effects of tempol and other nitroxides. Pharmacol Rev 60: 418-469.

[215] Dekhuijzen, P.N. (2004) Antioxidant properties of N-acetylcysteine: their relevance in relation to chronic obstructive pulmonary disease. Eur Respir J 23: 629-636.

[216] Moldeus, P., Cotgreave, I.A., Berggren, M. (1986) Lung protection by a thiol- containing antioxidant: N-acetylcysteine. Respiration 50 Suppl 1: 31-42.

[217] Heard, K.J. (2008) Acetylcysteine for acetaminophen poisoning. N Engl J Med 359: 285292.

[218] Yilmaz, H., Sahin, S., Sayar, N., Tangurek, B., Yilmaz, M., Nurkalem, Z., Onturk, E., Cakmak, N., Bolca, O. (2007) Effects of folic acid and N-acetylcysteine on plasma homocysteine levels and endothelial function in patients with coronary artery disease. Acta Cardiol 62: 579-585.

[219] Beckman, J.S., Minor, R.L., Jr., White, C.W., Repine, J.E., Rosen, G.M., Freeman, B.A. (1988) Superoxide dismutase and catalase conjugated to polyethylene glycol increases endothelial enzyme activity and oxidant resistance. J Biol Chem 263: 6884-6892.

[220] Zhao, R., Masayasu, H., Holmgren, A. (2002) Ebselen: a substrate for human thioredoxin reductase strongly stimulating its hydroperoxide reductase activity and a superfast thioredoxin oxidant. Proc Natl Acad Sci U S A 99: 8579-8584.

[221] Schewe, T. (1995) Molecular actions of ebselen--an antiinflammatory antioxidant. Gen Pharmacol 26: 1153-1169.

[222] Arakawa, M., Ito, Y. (2007) N-acetylcysteine and neurodegenerative diseases: Basic and clinical pharmacology. Cerebellum: 1-7.

[223] Masumoto, H., Sies, H. (1996) The reaction of ebselen with peroxynitrite. Chem Res Toxicol 9: 262-267.

[224] Saito, I., Asano, T., Sano, K., Takakura, K., Abe, H., Yoshimoto, T., Kikuchi, H., Ohta, T., Ishibashi, S. (1998) Neuroprotective effect of an antioxidant, ebselen, in patients with delayed neurological deficits after aneurysmal subarachnoid hemorrhage. Neurosurgery 42: 269-277; discussion 277-268.

[225] Yamaguchi, T., Sano, K., Takakura, K., Saito, I., Shinohara, Y., Asano, T., Yasuhara, H. (1998) Ebselen in acute ischemic stroke: a placebo-controlled, double-blind clinical trial. Ebselen Study Group. Stroke 29: 12-17.

[226] Gilgun-Sherki, Y., Rosenbaum, Z., Melamed, E., Offen, D. (2002) Antioxidant therapy in acute central nervous system injury: current state. Pharmacol Rev 54: 271-284.

[227] Kizhakekuttu, T.J., Widlansky, M.E. (2010) Natural antioxidants and hypertension: promise and challenges. Cardiovasc Ther 28: e20-32.

[228] Zingg, J.M. (2007) Modulation of signal transduction by vitamin E. Mol Aspects Med 28: 481-506. 
[229] Chen, X., Touyz, R.M., Park, J.B., Schiffrin, E.L. (2001) Antioxidant effects of vitamins C and $E$ are associated with altered activation of vascular NADPH oxidase and superoxide dismutase in stroke-prone SHR. Hypertension 38: 606-611.

[230] Carr, A., Frei, B. (1999) Does vitamin C act as a pro-oxidant under physiological conditions? FASEB J 13: 1007-1024.

[231] Carr, A.C., Zhu, B.Z., Frei, B. (2000) Potential antiatherogenic mechanisms of ascorbate (vitamin C) and alpha-tocopherol (vitamin E). Circ Res 87: 349-354.

[232] Shay, K.P., Moreau, R.F., Smith, E.J., Smith, A.R., Hagen, T.M. (2009) Alpha-lipoic acid as a dietary supplement: molecular mechanisms and therapeutic potential. Biochim Biophys Acta 1790: 1149-1160.

[233] Kim, S.H., Han, S.I., Oh, S.Y., Chung, H.Y., Kim, H.D., Kang, H.S. (2001) Activation of heat shock factor 1 by pyrrolidine dithiocarbamate is mediated by its activities as prooxidant and thiol modulator. Biochem Biophys Res Commun 281: 367-372.

[234] Schreck, R., Meier, B., Mannel, D.N., Droge, W., Baeuerle, P.A. (1992) Dithiocarbamates as potent inhibitors of nuclear factor kappa B activation in intact cells. J Exp Med 175: 1181-1194.

[235] Min, Y.K., Park, J.H., Chong, S.A., Kim, Y.S., Ahn, Y.S., Seo, J.T., Bae, Y.S., Chung, K.C. (2003) Pyrrolidine dithiocarbamate-induced neuronal cell death is mediated by Akt, casein kinase 2, c-Jun N-terminal kinase, and IkappaB kinase in embryonic hippocampal progenitor cells. J Neurosci Res 71: 689-700.

[236] Knowles, R.G., Moncada, S. (1994) Nitric oxide synthases in mammals. Biochem J 298 ( Pt 2): 249-258.

[237] Vasquez-Vivar, J., Kalyanaraman, B., Martasek, P., Hogg, N., Masters, B.S., Karoui, H., Tordo, P., Pritchard, K.A., Jr. (1998) Superoxide generation by endothelial nitric oxide synthase: the influence of cofactors. Proc Natl Acad Sci U S A 95: 9220-9225.

[238] Linscheid, P., Schaffner, A., Schoedon, G. (1998) Modulation of inducible nitric oxide synthase mRNA stability by tetrahydrobiopterin in vascular smooth muscle cells. Biochem Biophys Res Commun 243: 137-141.

[239] Kojima, S., Ona, S., Iizuka, I., Arai, T., Mori, H., Kubota, K. (1995) Antioxidative activity of 5,6,7,8-tetrahydrobiopterin and its inhibitory effect on paraquat-induced cell toxicity in cultured rat hepatocytes. Free Radic Res 23: 419-430.

[240] Park, Y.M., Park, M.Y., Suh, Y.L., Park, J.B. (2004) NAD(P)H oxidase inhibitor prevents blood pressure elevation and cardiovascular hypertrophy in aldosterone-infused rats. Biochem Biophys Res Commun 313: 812-817.

[241] Hu, L., Zhang, Y., Lim, P.S., Miao, Y., Tan, C., McKenzie, K.U., Schyvens, C.G., Whitworth, J.A. (2006) Apocynin but not L-arginine prevents and reverses dexamethasoneinduced hypertension in the rat. Am J Hypertens 19: 413-418.

[242] Zhang, Y., Chan, M.M., Andrews, M.C., Mori, T.A., Croft, K.D., McKenzie, K.U., Schyvens, C.G., Whitworth, J.A. (2005) Apocynin but not allopurinol prevents and reverses adrenocorticotropic hormone-induced hypertension in the rat. Am J Hypertens 18: 910-916.

[243] Costa, C.A., Amaral, T.A., Carvalho, L.C., Ognibene, D.T., da Silva, A.F., Moss, M.B., 
Valenca, S.S., de Moura, R.S., Resende, A.C. (2009) Antioxidant treatment with tempol and apocynin prevents endothelial dysfunction and development of renovascular hypertension. Am J Hypertens 22: 1242-1249.

[244] Pechanova, O., Jendekova, L., Vrankova, S. (2009) Effect of chronic apocynin treatment on nitric oxide and reactive oxygen species production in borderline and spontaneous hypertension. Pharmacol Rep 61: 116-122.

[245] Tian, N., Moore, R.S., Phillips, W.E., Lin, L., Braddy, S., Pryor, J.S., Stockstill, R.L., Hughson, M.D., Manning, R.D., Jr. (2008) NADPH oxidase contributes to renal damage and dysfunction in Dahl salt-sensitive hypertension. Am J Physiol Regul Integr Comp Physiol 295: R1858-1865.

[246] Armando, I., Wang, X., Villar, V.A., Jones, J.E., Asico, L.D., Escano, C., Jose, P.A. (2007) Reactive oxygen species-dependent hypertension in dopamine D2 receptor-deficient mice. Hypertension 49: 672-678.

[247] Kopkan, L., Huskova, Z., Vanourkova, Z., Thumova, M., Skaroupkova, P., Maly, J., Kramer, H.J., Dvorak, P., Cervenka, L. (2009) Reduction of oxidative stress does not attenuate the development of angiotensin II-dependent hypertension in Ren-2 transgenic rats. Vascul Pharmacol 51: 175-181.

[248] Liu, F., Wei, C.C., Wu, S.J., Chenier, I., Zhang, S.L., Filep, J.G., Ingelfinger, J.R., Chan, J.S. (2009) Apocynin attenuates tubular apoptosis and tubulointerstitial fibrosis in transgenic mice independent of hypertension. Kidney Int 75: 156-166.

[249] Ceravolo, G.S., Fernandes, L., Munhoz, C.D., Fernandes, D.C., Tostes, R.C., Laurindo, F.R., Scavone, C., Fortes, Z.B., Carvalho, M.H. (2007) Angiotensin II chronic infusion induces B1 receptor expression in aorta of rats. Hypertension 50: 756-761.

[250] Pech, V., Sikka, S.C., Sindhu, R.K., Vaziri, N.D., Majid, D.S. (2006) Oxidant stress and blood pressure responses to angiotensin II administration in rats fed varying salt diets. Am J Hypertens 19: 534-540.

[251] Zhou, M.S., Hernandez Schulman, I., Pagano, P.J., Jaimes, E.A., Raij, L. (2006) Reduced $\mathrm{NAD}(\mathrm{P}) \mathrm{H}$ oxidase in low renin hypertension: link among angiotensin II, atherogenesis, and blood pressure. Hypertension 47: 81-86.

[252] Viel, E.C., Benkirane, K., Javeshghani, D., Touyz, R.M., Schiffrin, E.L. (2008) Xanthine oxidase and mitochondria contribute to vascular superoxide anion generation in DOCAsalt hypertensive rats. Am J Physiol Heart Circ Physiol 295: H281-288.

[253] Wallwork, C.J., Parks, D.A., Schmid-Schonbein, G.W. (2003) Xanthine oxidase activity in the dexamethasone-induced hypertensive rat. Microvasc Res 66: 30-37.

[254] Szasz, T., Linder, A.E., Davis, R.P., Burnett, R., Fink, G.D., Watts, S.W. (2010) Allopurinol does not decrease blood pressure or prevent the development of hypertension in the deoxycorticosterone acetate-salt rat model. J Cardiovasc Pharmacol 56: 627-634.

[255] Ong, S.L., Vickers, J.J., Zhang, Y., McKenzie, K.U., Walsh, C.E., Whitworth, J.A. (2007) Role of xanthine oxidase in dexamethasone-induced hypertension in rats. Clin Exp Pharmacol Physiol 34: 517-519.

[256] Usui, M., Egashira, K., Kitamoto, S., Koyanagi, M., Katoh, M., Kataoka, C., Shimokawa, H., Takeshita, A. (1999) Pathogenic role of oxidative stress in vascular angiotensin-converting enzyme activation in long-term blockade of nitric oxide synthesis in rats. Hyperten- 
sion 34: 546-551.

[257] Laakso, J.T., Teravainen, T.L., Martelin, E., Vaskonen, T., Lapatto, R. (2004) Renal xanthine oxidoreductase activity during development of hypertension in spontaneously hypertensive rats. J Hypertens 22: 1333-1340.

[258] Nakazono, K., Watanabe, N., Matsuno, K., Sasaki, J., Sato, T., Inoue, M. (1991) Does superoxide underlie the pathogenesis of hypertension? Proc Natl Acad Sci U S A 88: 10045-10048.

[259] Park, J.B., Touyz, R.M., Chen, X., Schiffrin, E.L. (2002) Chronic treatment with a superoxide dismutase mimetic prevents vascular remodeling and progression of hypertension in salt-loaded stroke-prone spontaneously hypertensive rats. Am J Hypertens 15: 78-84.

[260] Beswick, R.A., Zhang, H., Marable, D., Catravas, J.D., Hill, W.D., Webb, R.C. (2001) Longterm antioxidant administration attenuates mineralocorticoid hypertension and renal inflammatory response. Hypertension 37: 781-786.

[261] Bayorh, M.A., Mann, G., Walton, M., Eatman, D. (2006) Effects of enalapril, tempol, and eplerenone on salt-induced hypertension in dahl salt-sensitive rats. Clin Exp Hypertens 28: 121-132.

[262] Dobrian, A.D., Schriver, S.D., Prewitt, R.L. (2001) Role of angiotensin II and free radicals in blood pressure regulation in a rat model of renal hypertension. Hypertension 38: 361366.

[263] Zhang, Y., Jang, R., Mori, T.A., Croft, K.D., Schyvens, C.G., McKenzie, K.U., Whitworth, J.A. (2003) The anti-oxidant Tempol reverses and partially prevents adrenocorticotrophic hormone-induced hypertension in the rat. J Hypertens 21: 1513- 1518.

[264] Elmarakby, A.A., Williams, J.M., Imig, J.D., Pollock, J.S., Pollock, D.M. (2007) Synergistic actions of enalapril and tempol during chronic angiotensin II-induced hypertension. Vascul Pharmacol 46: 144-151.

[265] Pechanova, O., Zicha, J., Kojsova, S., Dobesova, Z., Jendekova, L., Kunes, J. (2006) Effect of chronic N-acetylcysteine treatment on the development of spontaneous hypertension. Clin Sci (Lond) 110: 235-242.

[266] Mondo, C.K., Zhang, Y., de Macedo Possamai, V., Miao, Y., Schyvens, C.G., McKenzie, K.U., Hu, L., Guo, Z., Whitworth, J.A. (2006) N-acetylcysteine antagonizes the development but does not reverse ACTH-induced hypertension in the rat. Clin Exp Hypertens 28: 73-84.

[267] Tian, N., Rose, R.A., Jordan, S., Dwyer, T.M., Hughson, M.D., Manning, R.D., Jr. (2006) $\mathrm{N}$-Acetylcysteine improves renal dysfunction, ameliorates kidney damage and decreases blood pressure in salt-sensitive hypertension. J Hypertens 24: 2263-2270.

[268] Rauchova, H., Pechanova, O., Kunes, J., Vokurkova, M., Dobesova, Z., Zicha, J. (2005) Chronic $\mathrm{N}$-acetylcysteine administration prevents development of hypertension in $\mathrm{N}$ (omega)-nitro-L-arginine methyl ester-treated rats: the role of reactive oxygen species. Hypertens Res 28: 475-482.

[269] Jung, O., Marklund, S.L., Xia, N., Busse, R., Brandes, R.P. (2007) Inactivation of extracellular superoxide dismutase contributes to the development of high-volume hypertension. Arterioscler Thromb Vasc Biol 27: 470-477.

[270] Weber, D.S., Rocic, P., Mellis, A.M., Laude, K., Lyle, A.N., Harrison, D.G., Griendling, 
K.K. (2005) Angiotensin II-induced hypertrophy is potentiated in mice overexpressing p22phox in vascular smooth muscle. Am J Physiol Heart Circ Physiol 288: H37-42.

[271] Nishikawa, Y., Tatsumi, K., Matsuura, T., Yamamoto, A., Nadamoto, T., Urabe, K. (2003) Effects of vitamin $\mathrm{C}$ on high blood pressure induced by salt in spontaneously hypertensive rats. J Nutr Sci Vitaminol (Tokyo) 49: 301-309.

[272] Ettarh, R.R., Odigie, I.P., Adigun, S.A. (2002) Vitamin C lowers blood pressure and alters vascular responsiveness in salt-induced hypertension. Can J Physiol Pharmacol 80: 11991202.

[273] Tian, N., Moore, R.S., Braddy, S., Rose, R.A., Gu, J.W., Hughson, M.D., Manning, R.D., Jr. (2007) Interactions between oxidative stress and inflammation in salt-sensitive hypertension. Am J Physiol Heart Circ Physiol 293: H3388-3395.

[274] Schyvens, C.G., Andrews, M.C., Tam, R., Mori, T.A., Croft, K.D., McKenzie, K.U., Whitworth, J.A., Zhang, Y. (2007) Antioxidant vitamins and adrenocorticotrophic hormoneinduced hypertension in rats. Clin Exp Hypertens 29: 465-478.

[275] Noguchi, T., Ikeda, K., Sasaki, Y., Yamamoto, J., Yamori, Y. (2004) Effects of vitamin E and sesamin on hypertension and cerebral thrombogenesis in stroke-prone spontaneously hypertensive rats. Clin Exp Pharmacol Physiol 31 Suppl 2: S24-26.

[276] Vasdev, S., Ford, C.A., Parai, S., Longerich, L., Gadag, V. (2000) Dietary alpha-lipoic acid supplementation lowers blood pressure in spontaneously hypertensive rats. J Hypertens 18: 567-573.

[277] Vasdev, S., Ford, C.A., Parai, S., Longerich, L., Gadag, V. (2000) Dietary lipoic acid supplementation prevents fructose-induced hypertension in rats. Nutr Metab Cardiovasc Dis 10: 339-346.

[278] Vasdev, S., Gill, V., Longerich, L., Parai, S., Gadag, V. (2003) Salt-induced hypertension in WKY rats: prevention by alpha-lipoic acid supplementation. Mol Cell Biochem 254: 319-326.

[279] Takaoka, M., Kobayashi, Y., Yuba, M., Ohkita, M., Matsumura, Y. (2001) Effects of alpha-lipoic acid on deoxycorticosterone acetate-salt-induced hypertension in rats. Eur J Pharmacol 424: 121-129.

[280] Koeners, M.P., Braam, B., Joles, J.A. (2011) Perinatal inhibition of NF-kappaB has longterm antihypertensive effects in spontaneously hypertensive rats. J Hypertens 29: 11601166.

[281] Fortepiani, L.A., Reckelhoff, J.F. (2005) Treatment with tetrahydrobiopterin reduces blood pressure in male SHR by reducing testosterone synthesis. Am J Physiol Regul Integr Comp Physiol 288: R733-736.

[282] Zhang, Y., Pang, T., Earl, J., Schyvens, C.G., McKenzie, K.U., Whitworth, J.A. (2004) Role of tetrahydrobiopterin in adrenocorticotropic hormone-induced hypertension in the rat. Clin Exp Hypertens 26: 231-241.

[283] Kris-Etherton, P.M., Lichtenstein, A.H., Howard, B.V., Steinberg, D., Witztum, J.L. (2004) Antioxidant vitamin supplements and cardiovascular disease. Circulation 110: 637-641.

[284] Bjelakovic, G., Nikolova, D., Gluud, L.L., Simonetti, R.G., Gluud, C. (2007) Mortality in randomized trials of antioxidant supplements for primary and secondary prevention: systematic review and meta-analysis. JAMA 297: 842-857. 
[285] Dotan, Y., Pinchuk, I., Lichtenberg, D., Leshno, M. (2009) Decision analysis supports the paradigm that indiscriminate supplementation of vitamin $\mathrm{E}$ does more harm than good. Arterioscler Thromb Vasc Biol 29: 1304-1309.

[286] Bates, C.J., Walmsley, C.M., Prentice, A., Finch, S. (1998) Does vitamin C reduce blood pressure? Results of a large study of people aged 65 or older. J Hypertens 16: 925-932.

[287] McMackin, C.J., Widlansky, M.E., Hamburg, N.M., Huang, A.L., Weller, S., Holbrook, M., Gokce, N., Hagen, T.M., Keaney, J.F., Jr., Vita, J.A. (2007) Effect of combined treatment with alpha-Lipoic acid and acetyl-L-carnitine on vascular function and blood pressure in patients with coronary artery disease. J Clin Hypertens (Greenwich) 9: 249- 255.

[288] Rahman, S.T., Merchant, N., Haque, T., Wahi, J., Bhaheetharan, S., Ferdinand, K.C., Khan, B.V. (2012) The Impact of Lipoic Acid on Endothelial Function and Proteinuria in Quinapril-Treated Diabetic Patients With Stage I Hypertension: Results From the QUALITY Study, J Cardiovasc Pharmacol Ther 17: 139-145.

[289] John, J.H., Ziebland, S., Yudkin, P., Roe, L.S., Neil, H.A. (2002) Effects of fruit and vegetable consumption on plasma antioxidant concentrations and blood pressure: a randomised controlled trial. Lancet 359: 1969-1974.

[290] Lopes, H.F., Martin, K.L., Nashar, K., Morrow, J.D., Goodfriend, T.L., Egan, B.M. (2003) DASH diet lowers blood pressure and lipid-induced oxidative stress in obesity. Hypertension 41: 422-430.

[291] Griendling, K.K., FitzGerald, G.A. (2003) Oxidative stress and cardiovascular injury: Part II: animal and human studies. Circulation 108: 2034-2040.

[292] Steinhubl, S.R. (2008) Why have antioxidants failed in clinical trials? Am J Cardiol 101: 14D-19D.

[293] Suzuki, K. (2009) Anti-oxidants for therapeutic use: why are only a few drugs in clinical use? Adv Drug Deliv Rev 61: 287-289.

[294] Violi, F., Loffredo, L., Musella, L., Marcoccia, A. (2004) Should antioxidant status be considered in interventional trials with antioxidants? Heart 90: 598-602.

[295] Yusuf, S., Dagenais, G., Pogue, J., Bosch, J., Sleight, P. (2000) Vitamin E supplementation and cardiovascular events in high-risk patients. The Heart Outcomes Prevention Evaluation Study Investigators. N Engl J Med 342: 154-160.

[296] Montezano, A.C., Touyz, R.M. (2012) Molecular Mechanisms of Hypertension- Reactive Oxygen Species and Antioxidants: A Basic Science Update for the Clinician. Can J Cardiol.

[297] Violi, F., Cangemi, R. (2008) Statin treatment as a confounding factor in human trials with vitamin E. J Nutr 138: 1179-1181.

[298] George, J., Carr, E., Davies, J., Belch, J.J., Struthers, A. (2006) High-dose allopurinol improves endothelial function by profoundly reducing vascular oxidative stress and not by lowering uric acid. Circulation 114: 2508-2516.

[299] Kostka-Jeziorny, K., Uruski, P., Tykarski, A. (2011) Effect of allopurinol on blood pressure and aortic compliance in hypertensive patients. Blood Press 20: 104-110.

[300] Feig, D.I., Soletsky, B., Johnson, R.J. (2008) Effect of allopurinol on blood pressure of adolescents with newly diagnosed essential hypertension: a randomized trial. JAMA 300: 924-932. 
[301] Kanbay, M., Ozkara, A., Selcoki, Y., Isik, B., Turgut, F., Bavbek, N., Uz, E., Akcay, A., Yigitoglu, R., Covic, A. (2007) Effect of treatment of hyperuricemia with allopurinol on blood pressure, creatinine clearence, and proteinuria in patients with normal renal functions. Int Urol Nephrol 39: 1227-1233.

[302] Garrido, A.M., Griendling, K.K. (2009) NADPH oxidases and angiotensin II receptor signaling. Mol Cell Endocrinol 302: 148-158.

[303] Griendling, K.K., Ushio-Fukai, M. (2000) Reactive oxygen species as mediators of angiotensin II signaling. Regul Pept 91: 21-27.

[304] Tamba, M., Torreggiani, A. (2000) Free radical scavenging and copper chelation: a potentially beneficial action of captopril. Free Radic Res 32: 199-211.

[305] Chen, S., Ge, Y., Si, J., Rifai, A., Dworkin, L.D., Gong, R. (2008) Candesartan suppresses chronic renal inflammation by a novel antioxidant action independent of AT1R blockade. Kidney Int 74: 1128-1138.

[306] Kadowaki, D., Anraku, M., Tasaki, Y., Taguchi, K., Shimoishi, K., Seo, H., Hirata, S., Maruyama, T., Otagiri, M. (2009) Evaluation for antioxidant and renoprotective activity of olmesartan using nephrectomy rats. Biol Pharm Bull 32: 2041-2045.

[307] Miyata, T., van Ypersele de Strihou, C., Ueda, Y., Ichimori, K., Inagi, R., Onogi, H., Ishikawa, N., Nangaku, M., Kurokawa, K. (2002) Angiotensin II receptor antagonists and angiotensin-converting enzyme inhibitors lower in vitro the formation of advanced glycation end products: biochemical mechanisms. J Am Soc Nephrol 13: 2478-2487.

[308] Dandona, P., Ghanim, H., Brooks, D.P. (2007) Antioxidant activity of carvedilol in cardiovascular disease. J Hypertens 25: 731-741.

[309] Evangelista, S., Garbin, U., Pasini, A.F., Stranieri, C., Boccioletti, V., Cominacini, L. (2007) Effect of DL-nebivolol, its enantiomers and metabolites on the intracellular production of superoxide and nitric oxide in human endothelial cells. Pharmacol Res 55: 303-309.

[310] Gupta, S., Wright, H.M. (2008) Nebivolol: a highly selective beta1-adrenergic receptor blocker that causes vasodilation by increasing nitric oxide. Cardiovasc Ther 26: 189-202. Cominacini, L., Fratta Pasini, A., Garbin, U., Pastorino, A.M., Davoli, A., Nava, C.,

[311] Campagnola, M., Rossato, P., Lo Cascio, V. (2003) Antioxidant activity of different dihydropyridines. Biochem Biophys Res Commun 302: 679-684.

[312] Godfraind, T. (2005) Antioxidant effects and the therapeutic mode of action of calcium channel blockers in hypertension and atherosclerosis. Philos Trans R Soc Lond B Biol Sci 360: 2259-2272. 